Vol. 23, No. 4, pp. 358 388, 2020.

\title{
Review of Perovskite Solar Cells Using Metal-Organic Framework Materials
}

\author{
Do Yeon Heo, Soo Young Kim
}

Department of Materials Science and Engineering, Institute of Green Manufacturing Technology, Korea University

145 Anam-ro, Seongbuk-gu, Seoul 02841, Republic of Korea

\section{금속-유기 골격 물질을 사용한 페로브스카이트 태양전지 특성 리뷰}

\author{
허도연, 김수영 ${ }^{\dagger}$ \\ 고려대학교 신소재공학부
}

(Received October 28, 2020; Revised December 9, 2020; Accepted December 9, 2020)

\begin{abstract}
s
Metal-organic frameworks (MOFs) and MOF-derived materials have been used for several applications, such as hydrogen storage and separation, catalysis, and drug delivery, owing to have a significantly large surface area and open pore structure. In recent years, MOFs have also been applied to thin-film solar cells, and attractive results have been obtained. In perovskite solar cells (PSCs), the MOF materials are used in the form of an additive for electron and hole transport layers, interlayer, and hybrid perovskite/MOF. MOFs have the potential to be used as a material for obtaining PSCs with high efficiency and stability. In this study, we briefly explain the synthesis of MOFs and the performance of organic and dye-sensitized solar cells with MOFs. Furthermore, we provide a detailed overview on the performance of the most recently reported PSCs using MOFs.
\end{abstract}

Keywords: Metal organic framework (MOF), Perovskite solar cells

${ }^{\dagger}$ Corresponding Author: Soo Young Kim

E-mail: sooyoungkim@korea.ac.kr 


\section{1. 서론}

\section{1. 금속-유기 골격 구조 (MOFs)}

다공성 물질은 비표면적이 매우 크고, 기공을 통한 이 온이나 전자의 확산이 쉽고 빠르다는 장점으로 다양한 분야에서 활용되고 있다. 다공성 물질에는 다공성 세라 믹, 폴리머 폼, 다공성 유리, 활성탄, 다공성 금속, 제올 라이트 등이 있으며, 그 중 금속 유기 골격 물질 $(\mathrm{MOF})$ 이 최근 주목받고 있다. $\mathrm{MOF}$ 는 금속 이온과 유기 리간 드가 배위결합에 의해 연결되어 3차원적인 구조를 형성 하는 다공성 물질로, 유기-무기 하이브리드 화합물이다 (Fig. 1). MOF에서 무기 금속으로 transition metals, actinides, alkaline earth metals, mixed metals 등 이 주로 사용되며, 유기 linker로는 carboxylates, sulphates, phosphonates, azole, heterocyclic compounds 등이 있다. MOF는 표면적이 매우 넓을 뿐 만 아니라 열린 기공 구조를 가지고 있기 때문에 다른 다공성 물질에 비해 대량의 분자 또는 용매 등의 이동이 가능하다. 또한, $\mathrm{MOF}$ 는 금속-유기 리간드의 틀이나 성 분을 바꿀 수 있어서 다양한 특성을 보이고, 기공의 크 기를 조절할 수 있다는 훌륭한 장점이 있다. $\mathrm{MOF}$ 의 이 러한 장점은 에너지 분야, 수소 저장 및 분리 ${ }^{1-5)}$, 촉매 작용 ${ }^{6-8)}$, 약물 전달9,10)에 이르기까지 광범위한 응용분야 에 $\mathrm{MOF}$ 를 적용시킬 수 있다.

MOF에 대한 연구는 1990년 Robson ${ }^{11-12)}$, Yaghi ${ }^{13)}$, Kitagawa ${ }^{14)}$, ferey ${ }^{15)}$ 그룹에 의해 시작되었다. 특히, $\mathrm{MOF}$ 라는 용어는 1995년 Yaghi에 의해서 처음 소개되 었다. MOFs에 대한 연구는 계속 진행되었으며, 2012년

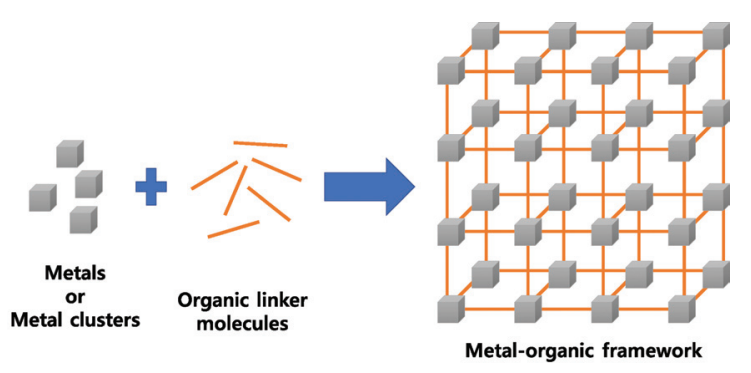

Fig. 1. Schematic of the MOF structure.
$\mathrm{Wu}$ 와 Yamauchi group $\mathrm{MOF}$-파생 재료를 소개한 이 후로 $\mathrm{MOFs}$ 에 대한 관심이 더욱 증가했다 ${ }^{16)} . \mathrm{MOF}$-파 생 재료는 $\mathrm{MOF}$ 전구체, 게스트 종 및 합성 조건을 변화 시켜 물질을 파생시킬 수 있기 때문에 다양한 하이브리 드 물질로 구성될 수 있다. $\mathrm{MOF}$ 구조가 가지는 높은 표 면적과 기공률, 향상된 안정성을 특징으로 하는 $\mathrm{MOF}-$ 파생 재료는 다양한 촉매로써 연구되고 있다 ${ }^{17,18)}$. 구조 적 변동성이 높은 $\mathrm{MOF}$ 및 $\mathrm{MOF}-$ 파생 재료는 에너지 관련 공정뿐만 아니라 다른 분야에서도 응용될 수 있는 잠재력을 가지고 있다. 최근 태양 광 기술의 급속한 발 전으로 에너지 응용 분야에서 $\mathrm{MOF}$ 재료를 활용한 연구 가 지속적으로 증가하고 있다. 우리는 $\mathrm{MOF}$ 의 합성법과 $\mathrm{MOF}$ 물질을 사용한 태양전지에 대해 요약하고자 한다. 특히, 실리콘 태양전지를 대체할 수 있는 차세대 태양전 지로 각광받는 페로브스카이트 태양전지에 $\mathrm{MOF}$ 를 적 용한 최근 연구를 종합적으로 요약했다.

\subsection{MOFs 합성 방법}

대부분 액체상태에서 $\mathrm{MOF}$ 합성을 진행하는데, 금속 염과 리간드 용액은 각각 제조한 후 섞거나 용매에 금 속염과 리간드를 첨가한다. 일반적으로 용해도가 높은 디메틸포름아미드, 아세토니트릴, 아세톤, 디에틸포름 아미드, 에탄올, 메탄올과 같은 유기 용매가 사용된다. 용매는 $\mathrm{MOF}$ 의 특성에 영향을 미치기 때문에 원하는 $\mathrm{MOF}$ 의 특징에 맞게 선택해야 한다. $\mathrm{MOF}$ 를 합성하는 몇 가지 방법을 소개하려고 한다. $\mathrm{MOF}$ 를 합성하는 방 법은 Fig. 2에 요약했다.

\subsection{1. 용매 열 합성법}

용매 열 합성법은 다양한 형태의 $\mathrm{MOF}$ 를 얻을 수 있기 때문에 $\mathrm{MOF}$ 합성에 가장 많이 사용된다. 유 기 용매 또는 혼합 용액의 금속 염과 유기 리간드 사 이에서 반응이 일어난다. 용매 열 합성법은 용매 의 끓는 점 보다 높은 온도에서 수행되며, 비교적 높 은 수율의 $\mathrm{MOF}$ 물질을 얻을 수 있다. 용매 열 합성 법은 재료의 형태 분포, 결정도, 크기를 정확하게 제 어할 수 있으며, 합성을 위해 용매뿐만 아니라 합 


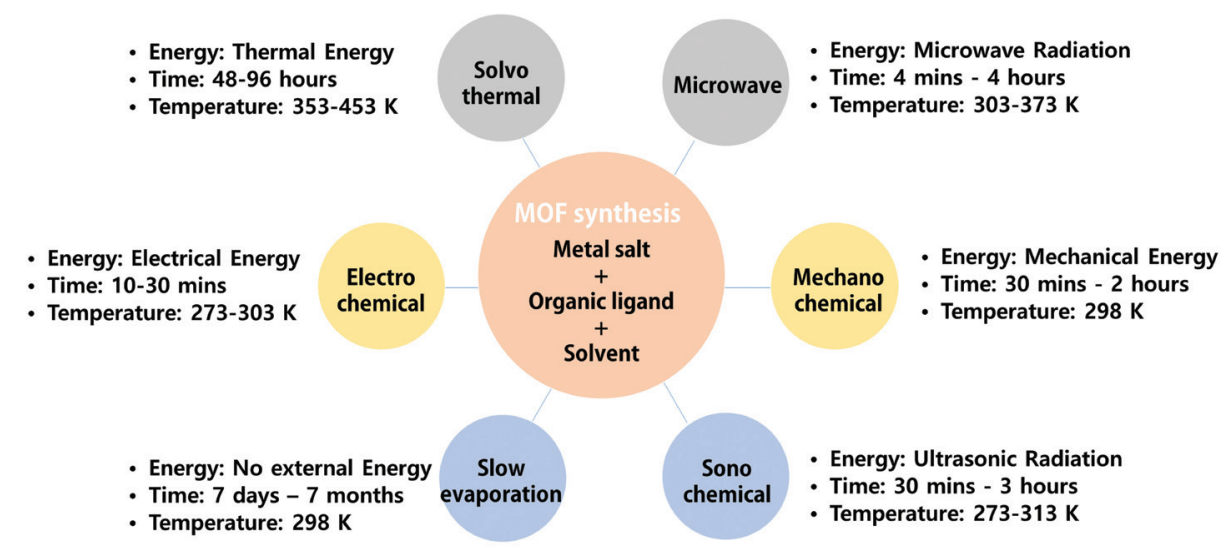

Fig. 2. Summary of various MOF synthesis methods.

성 온도, 반응물의 농도, 용액의 $\mathrm{pH}$ 를 고려해야한 다. Pachfule과 그의 동료들은 $\mathrm{Cu}\left(\mathrm{NO}_{3}\right)_{2} \cdot 3 \mathrm{H}_{2} \mathrm{O}, 4,4$, -(hexafluoroisopropylidene) bis(benzoic acid) $\left(\mathrm{C}_{17} \mathrm{H}_{10} \mathrm{~F}_{6} \mathrm{O}_{4}, \mathrm{H}_{2}\right.$ hfbba 과 $N, N$-dimethyl formamide $(\mathrm{DMF})$ 와 $\mathrm{N}, \mathrm{N}$-diethyl formamide (DEF) 용매에 존 재하는 terminal monodentate ligand 3-methyl pyridine (3-picoline/3-mepy)의 용매 열 반응으로 2개의 구조적으로 상이한 이차원 fluorinated MOFs $(\mathrm{F}-\mathrm{MOFS})$ 를 합성하는데 성공했다 ${ }^{19)}$. 용매 선택의 효 과는 합성한 $\mathrm{MOF}$ 구조에 명확하게 반영되었다. 그들 은 중합체 골격의 합성을 위한 용매가 적절한 조건 하 에서 상이한 정도의 $\mathrm{H}_{2} \mathrm{hfbba}$ 의 탈 양성자화에 기인한 결과 물질의 다양한 변화를 초래하는 것을 확인했다. Yang 그룹은 이방성 기공 구조와 $\mathrm{CO}_{2}$ 에 대한 친화력 을 가진 제올라이틱-이미다졸 골격구조-78 ( $\mathrm{ZIF}-78)$ 을 용매 열 합성법으로 형태를 제어하는 연구를 했다 ${ }^{20)}$. 그들은 육각 막대 형상을 갖는 ZIF-78 미세 결정을 트 리에틸아민을 통해 제조하였고, $\mathrm{ZIF}-78$ 마이크로 로드 의 크기와 종횡비를 자양분 농도, 리간드 농도, $\mathrm{nIm}$ 대 $\mathrm{nbIm}$ 의 상대 몰비를 변화시켜 "slender"에서 "squat" 로 조정했다. 최근 Wang 등은 간단한 용매 열 합성법 으로 꽃 줄 같은 $\mathrm{NiCo}-\mathrm{MOF}$ /다중-벽 탄소 나노튜브 (MWCNT) 복합체 합성에 성공했다 ${ }^{21)}$. MWCNT는 바이 메탈 $\mathrm{NiCo}-\mathrm{MOF}$ 성장을 위한 기판으로 사용되었고, 4 , 4'-biphenyldicarboxylic acid를 리간드로 사용했다.
그들은 $\mathrm{MWCNT}$ 의 존재가 $\mathrm{NiCo}-\mathrm{MOF}$ 결정의 형성에 영향을 미치지 않는 것을 확인했다. MWCNT는 $\mathrm{NiCo}-$ $\mathrm{MOF}$ 성장의 guiding 역할을 하며, MWCNT 투여량을 조절함으로써 잘 분산된 많은 꽃 줄 같은 구조를 얻을 수 있다. 용매 열 합성법의 하나의 단점은 기공으로부 터 용매 분자를 제거해야 하는 복잡한 과정이며, 일반적 으로 진공건조 또는 에탄올, 메탄올과 같은 용매에 의한 세척을 통해 이뤄진다.

\subsection{2. 마이크로파 합성법}

빠르게 MOF를 합성할 수 있는 방법으로 마이크로파 합성법을 많이 사용한다. 이 합성은 마이크로파를 사용 하여 적은 반응시간 뿐만 아니라 더 높은 결정도, 다공 성 텍스처 개발, 형태 제어, 입자크기 감소 등의 장점 을 가진 합성법이다. $\mathrm{Ni}$ 등은 몇 시간 또는 며칠이 걸리 던 $\mathrm{MOF}$ 합성을 마이크로파 합성법을 이용하여 30 초에 서 120 초안에 성공했다 ${ }^{22)}$. 또한 그들은 수율을 $30 \%$ 에서 $90 \%$ 이상으로 증가시켰다. 반응물의 농도를 조절함으로 써 결정의 크기를 변화시킬 수 있으며, 모든 결정이 한 번에 핵화 되기 때문에 핵 생성 과정을 제어할 수 있어 작은 크기의 결정을 합성할 수 있다. Vakili 등은 마이크 로파 합성법으로 지르코늄 기반 $\mathrm{MOF}$ 합성에 성공했으 며, 변조제(벤조산, 염산)의 양과 합성온도, 합성 시간을 조절하여 $\mathrm{MOF}$ 의 수율 및 다공성 특성을 최적화했다 ${ }^{23)}$. 


\subsection{3. 느린 증발법}

느린 증발법은 용매 또는 용매의 혼합물에 용해된 전 구체를 비활성 분위기에서 느린 증발에 의해 점진적으 로 농축하여 $\mathrm{MOF}$ 를 제조하는 방법이다. 용매의 혼합물 을 사용하여 용해도를 증가 외부에너지 공급없이 $\mathrm{MOF}$ 를 합성할 수 있는 장점이 있지만 시간이 많이 걸리는 프로세스이다. Cui 등은 느린 증발법으로 구형 콜로이드 결정을 3차원 정렬 호스트 매트릭스로 사용하여 $\mathrm{MOF}$ 합성에 성공했다 ${ }^{24)}$. 그들이 합성한 $\mathrm{MOF}$-광 콜로이드 결정은 광학적 특성, 자기-보고 신호 전달을 통한 특정 분자인식, 유도체화 능력, 이방성을 가지며, 고유한 광 밴드갭 구조로 광 물리학적 및 광 화학적 거동을 조작을 편리하게 한다.

\subsection{4. 기계화학 합성법}

물질 간의 기계적 교반과 충돌을 기반으로 하는 기계 적인 힘의 도움으로 화학 반응을 일으키는 기계화학 합 성법은 발암성, 독성 및 환경에 유해한 유기 용매 없 이 반응이 일어난다는 장점을 가지고 있다. 금속 염 대 신 금속 산화물이 일반적으로 시작물질로 사용된다. 용 매를 사용하지 않기 때문에 가열이 필요하지 않아 에너 지를 절약할 수 있고, 간단한 공정으로 고효율 결정을 얻을 수 있다. Li group은 수 분내에 높은 BrunauerEmmett-Teller (BET) 면적을 갖는 MOF-5를 합성하 기 위해 기계화학 합성법을 제안했다 ${ }^{25)}$. 그들은 용매 활 성화가 $\mathrm{MOF}-5$ 의 형성에 큰 영향을 미치는 것을 확인 하였고, 기계화학 합성법으로 최적화된 $\mathrm{MOF}-5-\mathrm{B}$ 가 저압에서 짧은 alkanes 보다 긴 alkanes에 대해 우선적 인 흡착을 나타낸 것을 확인했다. 또한, 기계화학적 합 성법으로 $\mathrm{MOF}-505$ 합성에 성공하였고, 첨가된 용매의 유형 및 양이 $\mathrm{MOF}-505$ 의 기계화학 합성에 결정적인 파라미터라는 것을 확인했다 ${ }^{26)}$.

\subsection{5. 초음파화학 합성법}

초음파 $(20 \mathrm{kHz}-10 \mathrm{MHz})$ 를 통해 $\mathrm{MOF}$ 를 합성하는 방 법이다. 반응 혼합물의 용액이 초음파에 노출되면 분자 가 화학적 변화를 거쳐 새로운 형태와 독특한 특성을 갖
는 화합물을 생성한다. 초음파는 액상에서 작은 기포의 형성과 성장을 포함하여 화학적 또는 물리적 변형을 일 어나게 한다. 이러한 기포의 붕괴는 고온 및 압력으로 짧은 수명의 국소 열 점을 생성하여 균일하게 핵 생성이 일어난다. 또한 초음파 화학 합성법은 통상적인 용매 열 합성법보다 결정화 시간을 감소시킬 수 있다. 2008년 $\mathrm{Ahn}$ 그룹은 초음파화학 합성법으로 $\mathrm{MOF}-5$ 결정을 처 음으로 제작하는데 성공했다 ${ }^{27)}$. 초음파화학 합성법으로 합성한 $\mathrm{MOF}-5$ 결정은 통상적인 대류 가열 하에서 제조 된 결정의 특성과 유사하지만 합성시간이 감소되고, 상 당히 작은 크기이다. 또한, 그들은 트리에틸아민(TEA) 을 양성자 제거제로 첨가한 후 같은 방법으로 $\mathrm{Mg}-$ $\mathrm{MOF}-74$ 결정을 1 시간 내에 성공적으로 제조했다 ${ }^{28)}$. 초음파화학 합성법으로 합성한 $\mathrm{Mg}-\mathrm{MOF}-74$ 는 $\mathrm{CO}_{2}$ 에 대한 우수한 선택성과 우수한 촉매 성능을 보였다.

\subsection{6. 전기화학 합성법}

전기화학 합성법은 금속 염을 필요로 하지 않기 때문 에 염분의 금속과 관련된 음이온을 피할 수 있어서 순 도 높은 물질을 얻을 수 있다. 전기화학 합성법은 염 전구체 대신 전극의 산화에 의해 금속 이온이 공급된 다. 적절한 전압 또는 전류를 인가하면, 금속이 용해되 고 $\mathrm{MOF}$ 형성에 필요한 금속 이온이 전극 표면 근처에 서 방출된다. 금속 이온은 용액에 존재하는 링커와 즉 시 반응하고 $\mathrm{MOF}$ 는 전극 표면에 가깝게 형성되기 때 문에 필름 균열이 줄어든다. Campagnol 등은 처음으 로 MIL- $100(\mathrm{Fe})$ 를 전기화학 합성법을 사용하여 합성 했다 ${ }^{29)}$. 이 기술은 더 온화한 조건하에서 반응이 일어나 기 때문에 $\mathrm{MIL}-100(\mathrm{Fe})$ 의 경우와 같이 저온에서 합성 할 수 없는 다른 $\mathrm{MOF}$ 의 생산 및 증착을 위한 길을 열어 주었다. Yang 등은 Zinc nitrate을 부분 금속 공급원으 로 사용하고 terephthalic acid를 유기 리간드로 사용한 1-butyl-3-methylimidazole bromide 이온 액체 시 스템에서 전기화학적 방법으로 $\mathrm{MOF}-5$ 를 성공적으로 합성했다 ${ }^{30)}$. 1,4-benzene-dicarboxylate와 $\mathrm{Zn}^{2+}$ 사 이의 배위 효과는 $\mathrm{MOF}-5$ 의 결정화를 유도하고 템플릿 구성에 따라 무한 네트워크를 형성한다. 


\subsection{7. 이외의 MOFs 합성법}

$\mathrm{MOF}$ 를 합성하는 다른 방법으로는 확산 법, 분무-건 조 방법, 이온 열 방식이 있다 ${ }^{31}$. 확산 법은 기상, 액상, 겔 확산으로 나눌 수 있는데, 사용되는 용매가 다르다. 기상 확산 법에서는 휘발성 유기 리간드 용액이 용매로 써 사용되고, 액상 확산 법에서는 유기 리간드와 금속 이온이 비혼화성 용매에 용해된다. 겔 확산으로의 $\mathrm{MOF}$ 결정 합성은 겔 물질에 분산된 금속 이온 용액 및 유기 리간드의 혼합물에서 발생한다. 확산 법은 온화한 반응 조건 하에서 수행되지만, 반응시간이 길다는 단점이 있 다. 분무-건조 방법은 우체 노즐을 사용하여 $\mathrm{MOF}$ 전 구체 용액을 미세 방울 분무로 분무하는 것으로, 용매가 증발하면 임계 농도에 도달할 때까지 표면에서 전구체 농도가 증가하고 결정화가 시작된다. 이온 열 방식은 구 조 템플릿, 반응 매질, 전하 균형 그룹으로 사용하는 이 온성 액체의 조성을 변화시킴으로써 $\mathrm{MOF}$ 의 물리 화학 적 특성을 제어할 수 있다.

\section{2. 태양전지에서 MOFs 활융}

\section{1. 태양전지}

태양전지는 태양의 빛에너지를 전기에너지로 변환시 켜 전기를 발생하는 장치이다. 빛에너지를 전기에너지 로 바꿀 수 있다는 점에서 신재생에너지로 주목받고 있 다. 또한, 태양전지는 화력, 원자력 발전소와는 다르게 전력을 생산하는 과정에서 유해한 물질을 방출하지 않 아 친환경적이다. 태양 전지는 광전지 효과를 기반으로 작동하며, 전지 표면에 조사되면 전압과 전류가 생성된 다. 광전지 효과는 캐리어 (전자 또는 정공)가 물질 내부 에서 여기 되어 전압 또는 전류를 생성하는 것이다. 빛 에너지보다 작은 밴드 갭을 갖는 태양전지의 반도체는 빛을 받아 에너지를 흡수하고, valence band 내의 전자 를 conduction band로 여기 시킬 수 있다. 여기 된 전 자는 외부 전압에 의해 전류로 흐른다. 외부 전압 환경 은 $\mathrm{p}$-타입 반도체와 $\mathrm{n}$-타입 반도체를 접합하여 만든 다. 이럴 경우, 두 반도체의 서로 다른 Fermy 에너지에 의해 계면에서 밴드 벤딩(band bending)이 일어나게 되
면, 이로 인해 $\mathrm{p}$-타입의 반도체와 $\mathrm{n}$-타입의 반도체 사 이에 전기장이 생기게 된다. 즉, 빛을 받아 전도대로 여 기 된 전자는 $\mathrm{p}-\mathrm{n}$ 접합의 밴드 벤딩에 의해 $\mathrm{p}$-타입 반 도체에서 $\mathrm{n}$-타입 반도체 방향으로 이동할 수 있게 되어 전류가 발생하고, 회로를 따라 흘러 에너지원으로 사용 이 가능하다.

태양전지의 효율을 결정하는 변수는 개방회로전압 (Voc), 단락 전류 (Jsc), fill factor $(\mathrm{FF})$, 전력변환효율 $(\mathrm{PCE})$ 가 있다. $\mathrm{Voc}$ 는 회로가 개방된 상태, 즉 무한대의 저항이 걸린 상태에서 빛을 받았을 때 태양전지의 양단 에 형성되는 전위차이다. 반도체의 밴드 갭에 의해 결정 되며, 밴드 갭이 큰 재료를 사용하면 대체로 높은 Voc 값이 얻어진다. Jsc는 회로가 단락 된 상태, 즉 외부저항 이 없는 상태에서 빛을 받았을 때 나타나는 역방향 (음 의 값)의 전류밀도이다. Jsc는 입사광의 세기와 스펙트 럼 분포에 따라 달라지지만, 이러한 조건이 결정된 상태 에서는 광흡수에 의해 여기 된 전자와 정공이 재결합하 여 손실되지 않고 얼마나 효과적으로 전지 내부에서 외 부회로 쪽으로 보내어지는가에 의존한다. 재결합에 의 한 손실은 재료의 내부나 계면에서 일어날 수 있다 ${ }^{32-34)}$. 태양전지 표면에서 태양빛의 반사를 최대한으로 하면 높은 Jsc를 얻을 수 있다. 이를 위해 반사 방지 코팅 35,36$)$ 이나 태양 빛을 가리는 면적을 최소화해주어 금속 접촉 을 만든다 ${ }^{37)}$. 가능한 모든 파장의 빛을 흡수하기 위해서 는 반도체의 밴드갭 에너지가 작을수록 유리하지만, 밴 드 갭이 작으면 Voc도 감소하게 되므로 적정한 밴드 갭 을 가진 재료가 필요하다. 최대 크기의 Voc와 Jsc 값을 얻기 위해 계산된 이론적인 최적의 밴드갭 에너지는 1.4 $\mathrm{eV}$ 가 된다. $\mathrm{FF}$ 는 빛이 가해진 상태에서 전류밀도-전압 곡선(J-V curve)이 얼마나 사각형에 가까운가를 나타 내는 값이다. $\mathrm{PCE}$ 는 태양광 면적당 출력량을 면적당 일 사량으로 나눈 값이다. $\mathrm{FF}$ 와 $\mathrm{PCE}$ 를 구하는 식은 아래 와 같다. $\mathrm{Vmp}$ 와 $\mathrm{Jmp}$ 는 최대 전력점에서의 전류밀도와 전압 값이다. 


$$
\begin{gathered}
F F=\frac{V_{M P} \times J_{M P}}{V_{O C} \times J_{S C}}, \\
P C E=\frac{V_{O C} \times J_{S C} \times F F}{P_{\text {input }}} \times 100,
\end{gathered}
$$

앞서 말했듯이, 태양전지에서 재료의 밴드 갭은 빛을 흡수할 수 있는 능력이기 때문에 적절한 밴드 갭을 가진 재료를 사용하는 것이 중요하다. 금속 이온과 유기 링커 로 구성된 $\mathrm{MOF}$ 는 구성 성분을 변화시켜 밴드갭 조절이 용이하다는 장점이 있다. 밀도 함수 이론을 사용하여 등 각 $\mathrm{MOF}$ (IRMOF)의 전자 밴드 구조가 조사됐다 ${ }^{38)}$. 할 로겐 원자가 $\mathrm{MOF}$ 의 밴드 갭뿐만 아니라 valence band $\operatorname{maximum}(\mathrm{VBM})$ 을 조정하는 작용기로써 사용될 수 있
는 것을 확인했다(Fig. 3 (a)). 특히 할로겐 원자 중에 서 iodine은 밴드 갭을 줄이고 $\mathrm{VBM}$ 을 높이는 가장 좋 은 후보이다. Guo 등은 두 개의 salicylic acid group을 가진 newnaphthalenediimide ligand (DSNDI) based $\mathrm{MOF}-74$ 을 디자인하였다 ${ }^{39)}$. 그들은 tetrathiafulvalene (TTF)를 DSNDI based MOF-74에 intercalation하여 $\mathrm{MOF}$ 의 밴드 갭을 $2.5 \mathrm{eV}$ 에서 $1.5 \mathrm{eV}$ 로 조절하는 데 성 공했다(Fig. 3 (b)). TTF 게스트에 의해 주입된 전자와 donor/acceptor stack을 통한 charge delocalization 으로 TTF-doped MOF의 conduction band는 Fermi level 근처에 남아있고, valence band는 크게 상승하여 밴드갭을 감소시킨다. 할로겐이온, TTF 도핑 이외에도 $\mathrm{Fe}$ 치환이 porphyrine 기반 $\mathrm{MOF}$ 의 밴드갭에 미치는 영 향이 연구되었다 ${ }^{40)}$. 그 결과, porphyrine metal center (a)

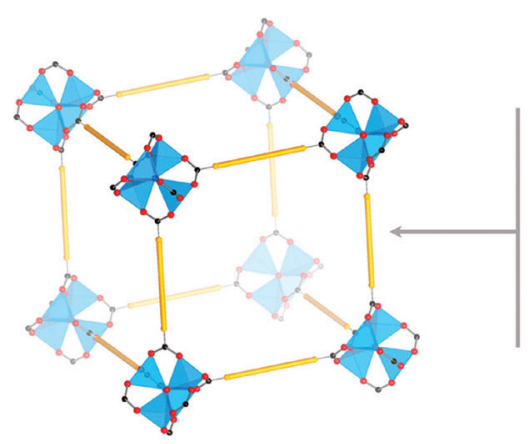

(b)

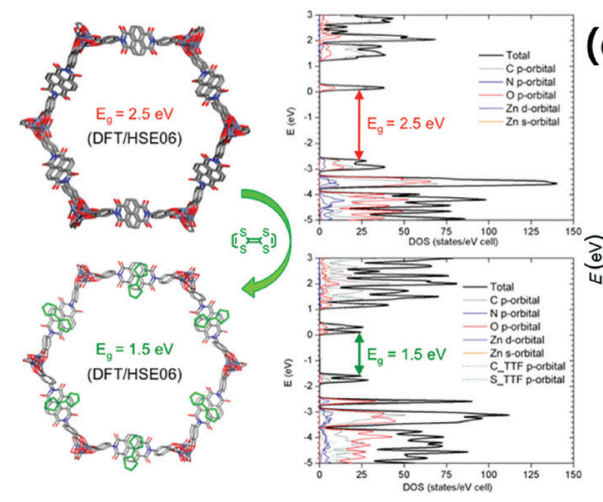

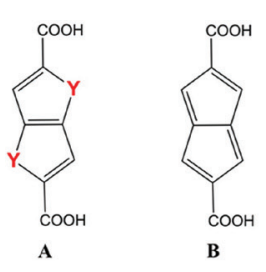

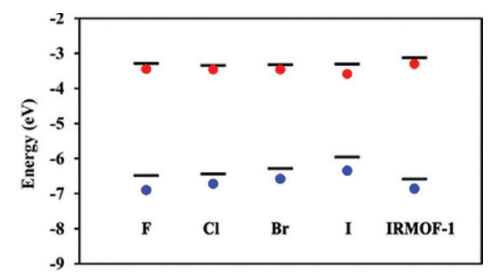

${ }_{\mathrm{COOH}}^{\mathrm{COOH}}$

C

$\mathrm{X}: \mathrm{H}, \mathrm{F}, \mathrm{Cl}, \mathrm{Br}, \mathrm{I}$

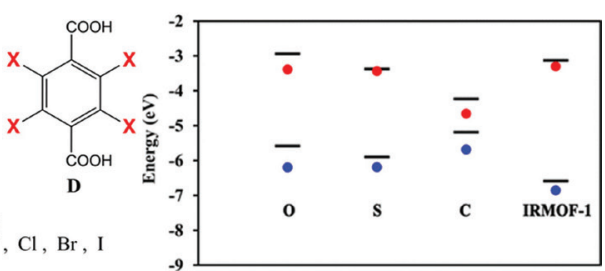

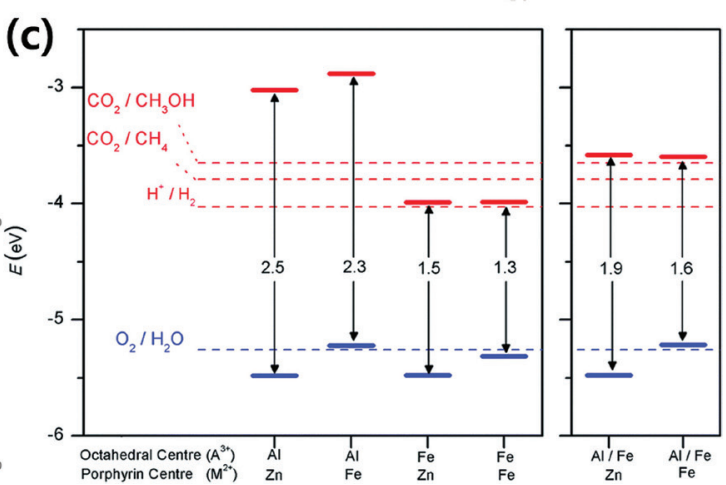

Fig. 3. (a) Schematic of the MOF and organic linkers (left) and band edge positions of the MOFs with various linkers (right) [38]. (b) Simulated structures (left) and the corresponding band structures (right) of DSNDI-based MOF-74. Upon TTF intercalation, the bandgap of the MOF drops from 2.5 to $1.5 \mathrm{eV}$ [39]. (c) Bandgaps and band edge positions, as calculated with the screened hybrid functional HSEO6 for (left) porphyrin-based MOF with only one element $(\mathrm{A}=\mathrm{Al}$ or $\mathrm{Fe})$ at the octahedral sites, and (right) mixed P-MOF with 50\% Al and 50\% Fe at the octahedral sites [40]. 


\section{특 집 ㅍㅃ 허도연, 김수영}

에 있는 $\mathrm{Fe}$ 가 valence band edge의 위치를 약간 올려 주는 효과가 있고, octahedral metal node에서의 $\mathrm{Fe}$ 는 절대 척도의 conduction band edge의 위치를 상당 히 낮추는 능력을 가진 것을 확인했다(Fig. 3 (c)). Fe는 $\mathrm{MOF}$ 의 밴드 구조 및 정렬을 설계하는 데 dopant로써 유용한 물질이다. 이 외에도 다양한 dopant, 금속, 유기 링커에 따라 밴드갭 조절이 가능하기 때문에 밴드 갭의 역할이 중요한 태양전지에 적용하기 적합한 물질이다 ${ }^{41-43)}$.

태양전지를 구성하는 재료의 종류에 따라 태양전지 를 구분할 수 있다. 가장 널리 알려져 있는 것이 실리콘 태양전지이다. 실리콘 태양전지는 실리콘의 결정 상태 에 따라 단결정 실리콘 태양전지, 다결정 실리콘 태양 전지, 비정질 실리콘 태양전지로 나눌 수 있다. 세 가지 의 실리콘 태양전지 중에서 단결정 실리콘 태양전지의 광 변환 효율이 가장 좋으나, 제작 비용이 비싸다는 단 점이 있다. 이와 같은 실리콘 기반의 태양전지를 1 세대 태양전지라고 한다 ${ }^{44)}$. 2 세대 태양전지는 박막 형태로 제 작된 태양전지를 말한다. 박막 태양전지에서 대표적으 로 활용되는 화합물 반도체는 copper indium gallium selenide (CIGS)이다 ${ }^{45)}$. CIGS 박막 태양전지는 결정질 실리콘에 비해 광흡수율이 높아 1 2 $\mu \mathrm{m}$ 의 두께만으로 도 고효율의 태양전지 제조가 가능하고 제고 공정이 실 리콘 태양전지에 비해 단순하여 제작 비용을 절감할 수 있다. 3 세대 태양전지는 2 세대 박막 태양전지를 기반으 로 하나, 사용되는 반도체 소재가 유기물 반도체 등과 같은 새로운 소재로 구성되어 있다. 유기물 반도체를 활 용함으로써 공정온도를 낮출 수가 있으며, 태양전지에 사용되는 기판 선택의 폭이 넓어졌다. 유연한 기판에 태 양전지를 제작할 수 있어 구부러지는 태양전지 제작이 가능해져서 다양한 응용분야에 적용할 수 있다. 여기서 부터 $\mathrm{MOF}$ 를 적용한 3세대 태양전지에 대해 설명하고자 한다.

\subsection{MOFs를 활용한 유기태양전지}

유기태양전지(OSCs)는 고도로 조정 가능한 구조, 저 비용 대면적 제조, 유연하고 반투명한 소자 등의 장점 을 가지고 있지만 $\mathrm{PCE}$ 가 낮다는 치명적인 단점이 있
다. 따라서 $\mathrm{OSCs}$ 의 $\mathrm{PCE}$ 와 안정성을 향상시키기 위한 연구가 많이 진행되고 있다 ${ }^{46-58)}$. OSCs에서 electron extraction layer (EEL)와 hole extraction layer (HEL)을 포함한 계면층은 매우 중요한 역할을 하며, 높 은 전도성과 전하 수송 이동성은 계면층의 중요한 특성 이다. 2 차원 재료는 넓은 표면적과 우수한 전자 및 광 학 특성으로 인해 계면층의 첨가제로 사용하기에 이상 적인 재료이다. 특히 전이금속 디칼코게나이드 (TMD) 는 광전자 특성, 양극성 전하 수송, 화학적 안정성, 단 일층 형태의 직접 밴드 갭으로 인해 상당히 매력적인 물 질로 알려져 있다 ${ }^{59)}$. 그러나 $\mathrm{TMD}$ 의 두께 및 확장성을 제어하는데 어려움이 있어 $\mathrm{TMD}$ 를 OSCs에 응용하기 엔 제한적이다. 따라서 $\mathrm{TMD}$ 의 우수한 특성을 포함하는 2D MOF가 OSCs에 응용되었다. Xing 등은 2D MOF nanosheet를 OSCs의 계면층으로 사용하여 OSCs를 연구했다 ${ }^{60)}$. 그들은 tellurophene-based 2 차원 $\mathrm{MOF}$ 와 branched polymer surfactant polyethylenimine ethoxylate (PEIE)를 박리하기 위한 효과적인 방법을 제안했다. 또한 그들은 합성한 PEIE-functionalized MOF nanosheet를 OSCs의 interlayer로 사용하여 기 존 $\mathrm{PEIE}$ 를 사용한 $\mathrm{OSCs}$ 보다 $\mathrm{PCE}$ 를 향상시키는 것에 성공했다. 태양광 성능이 향상된 이유는 $\mathrm{PEIE}-\mathrm{MOF}$ interfacial layer의 조정가능한 work function, 향상 된 전도도, $\mathrm{ZnO}$ film(EEL로 사용)의 산소 결함 부동 태화와 같은 특성 때문이다. 최근, Sasitharan 등은 ultrathin zinc-porphyrin based MOF nanosheets $(\mathrm{MONs})$ 를 합성했다 ${ }^{61)}$. MONs를 OSCs의 광 활성층으 로 사용한 소자는 사용하지 않은 기준 소자에 비해 거의 2 배인 $5.2 \%$ 의 $\mathrm{PCE}$ 를 나타냈다. $\mathrm{MONs}$ 의 전자, 광학적 및 구조적 특성으로 인해 $\mathrm{MONs}$ 는 poly(3-hexylthiophene-2,5diyl) (P3HT)의 결정화를 template 하기 위 한 표면으로써 사용되었다. 따라서 흡광도의 doubling, hole mobility의 증가, grain size 감소가 이루어져 $\mathrm{OSCs}$ 의 $\mathrm{PCE}$ 향상으로 이어진다. 이러한 결과는 광범 위한 OSCs의 성능을 향상시키기 위한 조정 가능한 2차 원 재료로써 MOF nanosheet의 잠재력을 보여준다. 


\section{3. $\mathrm{MOFs}$ 를 활용한 염료 감응형 태양전지}

염료 감응형 태양전지(DSSCS)는 저렴한 재료와 간단 한 제조 공정으로 제작이 가능하여 비용 효율적인 태양 전지로 알려져 있다. DSSCs는 titanium oxide $\left(\mathrm{TiO}_{2}\right)$ 와 천연 자원에서 추출할 수 있는 dye sensitizer로 구 성되었으며, 비싼 $\mathrm{Pt}$ 금속 대신 그래핀을 전극으로 사용 가능하다 ${ }^{62,63)}$. DSSCs는 유연한 기판에 인쇄하는 연속 적이고 저렴한 제조 방법인 roll-to-roll 공정이 가능하 다. 또한 흐린 날씨와 같은 어두운 조건에서도 확산 광 을 효과적으로 활용하여 잘 작동하기 때문에 DSSCs를 창문 및 선루프와 같은 다양한 응용 분야에 적용 가능하 다. $\mathrm{DSSCs}$ 의 장점으로 인해 집중적인 연구가 이루어 졌 다 ${ }^{64-69)}$.

$\mathrm{DSSCs}$ 의 Jsc와 $\mathrm{PCE}$ 를 개선하기 위한 큰 노력에 도 불구하고, $\mathrm{Voc}$ 는 $\mathrm{TiO}_{2} / \mathrm{dye}$ 와 $\mathrm{TiO}_{2} /$ 전해질 계면에 서의 전하 재결합으로 인해 상대적으로 낮다. $\mathrm{MOF}$ 는 $5000 \mathrm{~m}^{2} \mathrm{~g}^{-1}$ 보다 큰 $\mathrm{BET}$ 표면적을 갖는 나노 크기의 채널 및 cavity를 가진다 ${ }^{70)}$. 따라서 $\mathrm{MOF}$ 의 손쉬운 제작 과 다공성 특성은 DSSCs의 성능 향상을 위한 물질로 적 합하다. Wei 그룹은 $\mathrm{MOF}$ 를 $\mathrm{DSSCs}$ 의 $\mathrm{TiO}_{2}$ 전극을 코 팅하기 위해 처음 사용했다 ${ }^{71)}$. 그들은 $\mathrm{ZIF}-8$ 을 사용하 였고, $\mathrm{ZIF}-8$ 코팅층의 두께와 $\mathrm{Voc}$ 사이의 선형 관계를 발견했다. 또한 ZIF-8 shell 물질은 계면 전하 재결합 의 억제에 기인하며 $\mathrm{Voc}$ 를 향상시키는 데 도움을 준다. 이러한 결과는 DSSCs의 성능 향상에 $\mathrm{MOF}$ 물질이 기인
하며, MOF를 활용한 DSSCs 연구의 시발점이 되었다.

$\mathrm{MOF}$ 는 $\mathrm{DSSCs}$ 의 광 양극, 상대 전극, 전해질에 모 두 적용할 수 있다. Tang 등은 $\mathrm{Cu}_{2} \mathrm{ZnSnS}_{4}$ (CZTS) 나 노입자-sensitized MOFs-derived mesoporous $\mathrm{TiO}_{2}$ 를 합성하여 DSSCs의 photoanode로써 사용했다 ${ }^{72)}$. MOFs-derived $\mathrm{TiO}_{2}$ 는 MOFs 구조의 큰 비 표면적과 풍부한 다공성 구조를 포함한다. 그 결과 염료 로딩 능 력을 향상시키고, 다중 입자간 광 산란 공정을 향상시 켜 입사 광 진행 길이를 연장시킨다. CZTS 나노 입자와 MOFs-derived $\mathrm{TiO}_{2}$ 사이에 형성된 heterostructure 는 맞춰진 밴드 갭으로 인해 electron/hole pair의 재 결합 속도를 효과적으로 억제하고 carrier의 수명을 연 장시킨다(Fig. 4 (a)). 순수한 $\mathrm{TiO}_{2}$ 와 비교하여, CZTS/ $\mathrm{TiO}_{2}$ 의 비표면적은 크게 감소하고, micropore는 CZTS nanoparticles의 증착 후에 거의 사라지는 것을 확인 할 수 있다. CZTS/MOFs-derived $\mathrm{TiO}_{2}$ 기반 DSSCs 는 $\mathrm{TiO}_{2}$ 기반 $\mathrm{DSSCs}$ 보다 약 2 배 높은 $17.27 \mathrm{~mA} / \mathrm{cm}^{2}$ 의 최대 광전류와 $8.10 \%$ 의 광전 변환 성능을 보였다(Fig. 4 (b)). MOF 도입으로 인한 넓은 표면적을 갖는 다공성 구조는 계면 캐리어 수송, 염료 흡착 및 광 수확에 도움 을 주어 $\mathrm{DSSCs}$ 의 성능 향상에 큰 역할을 하는 것을 확 인할 수 있다.

탄소재료 ${ }^{73,74)}$, 전이 금속 재료 ${ }^{75-77)}$, 금속 합금 ${ }^{78)}$, 전도 성 폴리머 ${ }^{79)}$ 등을 사용하여 DSSCs의 상대전극으로 주 로 사용되는 Pt를 대체하기 위한 재료가 개발되었다. 탄
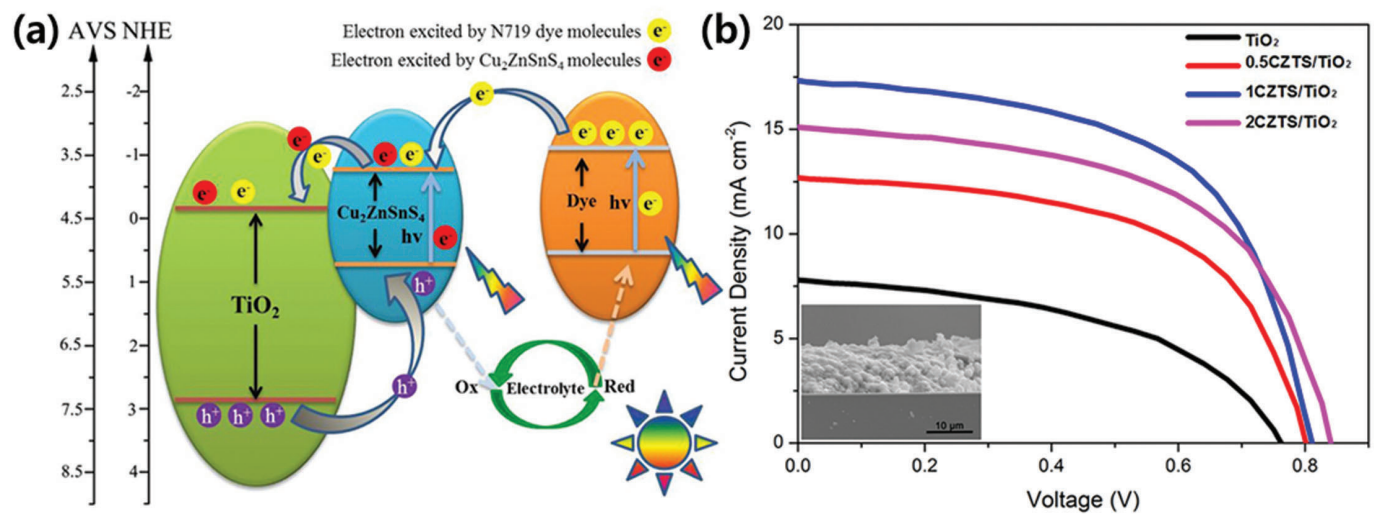

Fig. 4. (a) Energy band structure and photogenerated charge transfer mechanism in CZTS nanoparticles/MOF-derived TiO2. (b) Current density - voltage curves of $\mathrm{MOF}$-derived $\mathrm{TiO}_{2}$ and $\mathrm{CZTS} / \mathrm{TiO}_{2}$ samples [72]. 


\section{특 집 ㅍㅃ 허도연, 김수영}

소 재료는 높은 표면적과 높은 전기 전도성을 갖는 유 망한 비금속 전극 재료 중 하나지만 이들의 안정성은 비교적 열악하다. 탄소재료의 단점을 보완하기 위하여 $\mathrm{Ou}$ 등은 cobalt-metalloporphyin MOF 박막에서 파 생된 투명한 $\mathrm{CoS}_{1.097} @ \mathrm{~N}$ 도핑 된 탄소 막을 제작하고 $\mathrm{DSSCs}$ 의 상대전극으로 사용했다 ${ }^{80)} . \mathrm{N}$ 도핑 된 탄소 막 상에 균일하게 분산된 $\mathrm{CoS}_{1.097}$ 나노 입자는 큰 촉매 활 성 영역을 제공하고 전자 이동을 용이하게 하여 우수한 촉매 능력을 보였다. $\mathrm{CoS}_{1.097} @ \mathrm{~N}$ 도핑된 탄소 막은 $\mathrm{Pt}$ (8.04\% 와 5.87\%)보다 front 및 rear irradiation으로 부터 각각 $9.11 \%$ 와 $6.64 \%$ 의 더 높은 $\mathrm{PCE}$ 을 나타냈다. 또한 이들은 자연 조건 하에서 1000 시간에 걸쳐 우수한 장기 안정성을 보여 $\mathrm{Pt}$ 상대 전극의 대체제로 사용 가능 성을 나타냈다.

$\mathrm{MOF}$ 는 DSSCs 의 전해질에 첨가제로써 사용할 수 있 다. Bella 등은 UV-induced free-radical process를 통해 고분자 매트릭스에 $\mathrm{Mg}-\mathrm{MOF}$ 를 분산시켜 quasisolid DSSCs의 고분자 전해질 로 사용했다 ${ }^{81)} . \mathrm{Mg}-$ $\mathrm{MOF}$ 입자의 유기 쉘과 $\mathrm{TiO}_{2}$ 층의 표면 그룹 사이의 상 호 작용으로 인해 $4.8 \%$ 의 $\mathrm{PCE}$ 와 장기 내구성을 갖는 $\mathrm{DSSCs}$ 를 제작할 수 있었다. DSSCs에서 MOF의 사용 방법에 따른 광 성능을 Table. 1에 정리했다.

양자점 감응형 태양전지(QDSSCS)에 $\mathrm{MOF}$ 를 사용하

Table. 1. Photovoltaic performances of DSSCs with MOFs applied as the photoanode and counter electrode.

\begin{tabular}{|c|c|c|c|c|c|c|}
\hline & $\begin{array}{l}\text { MOF mate- } \\
\text { rial }\end{array}$ & $\begin{array}{l}V_{o C} \\
(V)\end{array}$ & $\begin{array}{c}\mathrm{J}_{\mathrm{SC}} \\
(\mathrm{mA} / \\
\left.\mathrm{cm}^{2}\right)\end{array}$ & $\mathrm{FF}$ & $\begin{array}{l}\mathrm{PCE} \\
(\%)\end{array}$ & ref \\
\hline \multirow{6}{*}{ Photoanode } & $\mathrm{ZIF}-8$ & 0.753 & 10.28 & 0.69 & 5.34 & 82 \\
\hline & MIL-125 & 0.85 & 10.9 & 0.69 & 6.4 & 83 \\
\hline & $\mathrm{Zn}$ & 0.68 & 6.22 & 0.55 & 2.34 & 84 \\
\hline & $\mathrm{NGE} / \mathrm{NiO}$ & 0.76 & 19.04 & 0.67 & 9.75 & 85 \\
\hline & ZIF-8 & 0.66 & 8.13 & 0.68 & 3.67 & 86 \\
\hline & $\mathrm{Ni}-\mathrm{MOF}$ & 0.624 & 27.32 & 0.516 & 8.84 & 87 \\
\hline \multirow{4}{*}{$\begin{array}{l}\text { Counter } \\
\text { electrode }\end{array}$} & $\mathrm{MOS}_{2} @ \mathrm{Co}_{3} \mathrm{~S}_{4}$ & 0.782 & 16.21 & 0.62 & 7.86 & 88 \\
\hline & $\begin{array}{c}\mathrm{CoSe}_{2}-\mathrm{NC} @ \\
\mathrm{Co}-\mathrm{FeSe}_{2}\end{array}$ & 0.806 & 17.9 & 0.66 & 9.61 & 89 \\
\hline & CoNi@CNTs & 0.76 & 18.3 & 0.65 & 9.04 & 90 \\
\hline & $\mathrm{ZIF}-8 / \mathrm{GO}$ & 0.77 & 15.25 & 0.69 & 8.2 & 91 \\
\hline
\end{tabular}

는 연구도 관심을 끌었다 ${ }^{92-96)}$. 양자점(QD)은 양자 감 쇄 효과, 넓은 광 흡수, 다중 여기자 생성 및 고체 증감 제로 사용되며, $\mathrm{MOF}$ 또한 그들의 화학적, 물리적 특성, 다공성, 장거리 내부 에너지 이동경로를 통해 감광제로 사용할 수 있다. Kaur 등은 광 촉매 특성을 가진 CdTe $\mathrm{QD} /$ Europium-MOF (Eu-MOF) 복합체를 QDSSCs 의 광양극으로 사용했다 ${ }^{97)}$. 그 결과, $\mathrm{CdTe} / \mathrm{Eu}-\mathrm{MOF}$ QDSSCs는 CdTe QDSSCs (PCE=1.67\%)보다 향상 된 $\mathrm{PCE}(3.02 \%)$ 를 나타냈다. 이러한 연구 결과는 $\mathrm{QD}$ 와 $\mathrm{MOF}$ 가 적절히 혼합되어 QDSSCs에서 광 수확 능력 을 향상시킬 수 있음을 시사한다. 상대전극으로써 ZIF67 의 잠재력은 $\mathrm{Xu}$ 등에 의해 연구되었다 ${ }^{98)}$. $\mathrm{Pt}$-상대 전극을 사용한 $\mathrm{CdSe} \mathrm{QDSSCs}$ 의 $\mathrm{PCE}(2.98 \%)$ 에 비해 ZIF-67 상대 전극을 사용한 QDSSCs는 3.77\%의 광전기 변환 효율을 나타냈다. 이 결과로 $\mathrm{MOF}$ 가 $\mathrm{Pt}$ 대신 QDSSCs의 상대 전극으로 적용될 수 있는 가능성을 나 타냈다.

최근 $\mathrm{MOF}$ 연구자들과 태양 광 연구자들은 촉매, 센 서 및 가스 저장과 같은 $\mathrm{MOF}$ 의 다른 주요 응용 분야 외 에도 태양 광 전지에서 $\mathrm{MOF}$ 를 활용하기 위해 많은 노 력을 기울였다. 그 중 $\mathrm{DSSCS}$ 에서 $\mathrm{MOF}$ 는 기존 광 양 극, 상대 전극, 전해질을 대체하거나 혼합하여 사용됐다 (Fig. 5).

높은 전기 전도성을 갖는 감광성 링커를 사용한 $\mathrm{MOF}$ 는 광양극으로 사용하기 적합하다. $\mathrm{MOF}$ 유래 물질은 고가의 Pt 전극을 대체하는 상대 전극으로 적용될 수 있 다. 전해질로 사용된 $\mathrm{MOF}$ 는 약간의 효율 향상과 장기 내구성 특성을 이끌었지만 아직 많은 연구가 이루어지 지 않았다. 앞서 언급했듯이 DSSCs는 저렴하고 간단한 제조공정으로 연구자들의 눈길을 끌었다. 그럼에도 불 구하고 액체 전해질과 낮은 효율은 상용화의 걸림돌이 된다. 액체 전해질을 대체하기 위한 페로브스카이트의 도입은 페로브스카이트 태양전지의 시작점이었다. 다음 으로 $\mathrm{MOF}$ 를 적용한 페로브스카이트 태양전지에 대해 소개한다. 


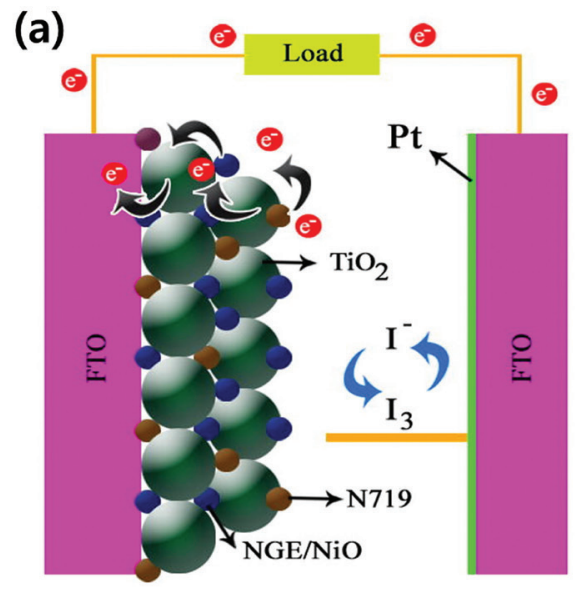

(b) $\mathrm{TiO}_{2}$ with $\mathrm{N} 719$ dye

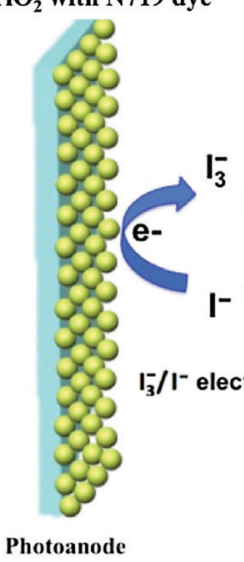

CoNi@CNTs-C

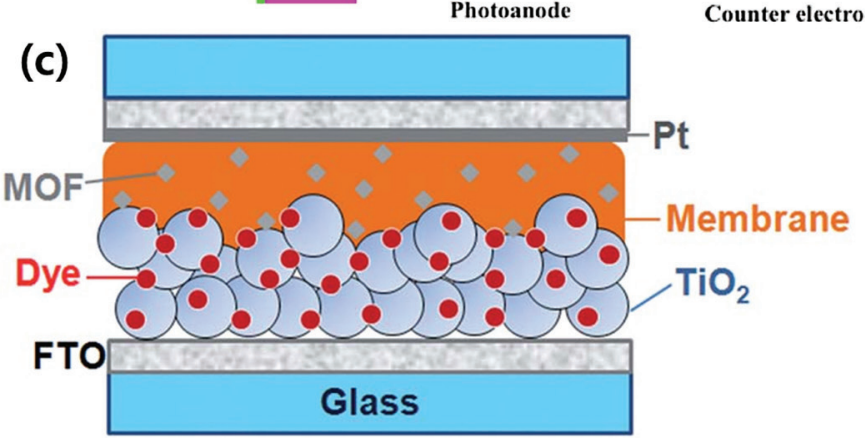

Fig. 5. Schematic of a DSSC configuration using MOFs as the (a) photoanode [85], (b) counter electrode [90], and (c) electrolyte [81].

\section{MOFs를 사융한 폐로브스카이트 태양전지}

페로브스카이트 태양전지(PSCs)의 PCE는 2009년 Miyasaka 그룹이 보고한 3.8\%에서 25.2\%까지 빠르 게 증가했다 ${ }^{99,100)}$. 페로브스카이트 구조의 일반 구조식 은 $\mathrm{ABX}_{3}$ 이며, 여기서 $\mathrm{A}$ 는 무기 또는 유기 양이온 $\left(\mathrm{Cs}^{+}\right.$, $\mathrm{Rb}^{+}, \mathrm{CH}_{3} \mathrm{NH}_{3}{ }^{+}, \mathrm{CH}_{2}\left(\mathrm{NH}_{2}\right)_{2}{ }^{+}$등 $), \mathrm{B}$ 는 2 가 금속 $\left(\mathrm{Pb}^{2+}\right.$, $\mathrm{Sn}^{2+}, \mathrm{Bi}^{2+}, \mathrm{Ge}^{2+}$ 등), $\mathrm{X}$ 는 할로겐화물 $\left(\mathrm{I}^{-}, \mathrm{Br}^{-}, \mathrm{Cl}^{-}\right.$또 는 이들의 혼합물, $\mathrm{SCN}^{-}$등)이 사용된다. 페로브스카 이 트는 낮은 재결합 손실, 저비용 공정, 긴 전하 캐리 어 확산 길이 및 손쉬운 밴드 갭 조정성을 나타내므로 광 흡수제로 사용하기에 적합하다. PSCs는 전도성 기 판 (fluorine-doped tin oxide; FTO 또는 indium tin oxide; ITO), 전자 수송 층 (ETL), 정공 수송 층 (HTL), 광 흡수제 (페로브스카이트 층) 및 금속 전극으로 구성 된다. PSCs는 주로 mesoporous 구조 또는 planar 구
조로 나뉘며 Fig. 6과 같이 표준 $(\mathrm{n}-\mathrm{i}-\mathrm{p})$ 및 inverted $(p-i-n)$ 구조로 더 분류될 수 있다 ${ }^{101}$.

$\mathrm{DSSCs}$ 에서 주로 사용되는 $\mathrm{TiO}_{2}$ 는 $\mathrm{PSCs}$ 에서도 전 자 수송 재료로 사용된다. Mesoporous 금속 산화물 층 은 페로브스카이트 막을 보호하고 페로브스카이트의 conduction band로부터 compact $\mathrm{TiO}_{2}$ 층으로 전자를 전달하는 scaffold 역할을 한다. Mesoscopic n-i-p 구 조는 가장 일반적으로 사용되며, 높은 효율을 얻었다. Mesoporous 층이 없는 planar 구조에서 빛은 유리 기 판을 통과하여 정공 수송 물질로 이동하고 상부 접촉 전 극이 완전히 가려질 수 있기 때문에 $\mathrm{PCE}$ 를 향상시킬 수 있다 ${ }^{102)}$. Inverted $(\mathrm{p}-\mathrm{i}-\mathrm{n})$ 구조는 전도성 기판 위에 $\mathrm{HTL}$, 페로브스카이트 층, ETL, 금속 음극 순으로 제작 한다. $\mathrm{p}-\mathrm{i}-\mathrm{n}$ 구조는 $\mathrm{n}-\mathrm{i}-\mathrm{p}$ 구조 보다 공정온도를 낮 출 수 있는 장점이 있지만 효율이 약간 낮다는 단점이 있다. 
(a) n-i-p mesoscopic

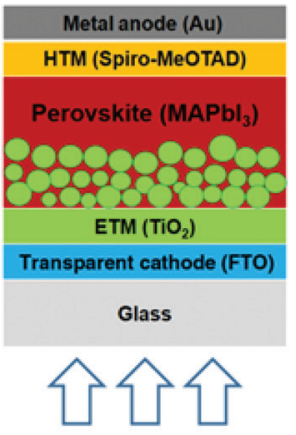

(b) n-i-p planar

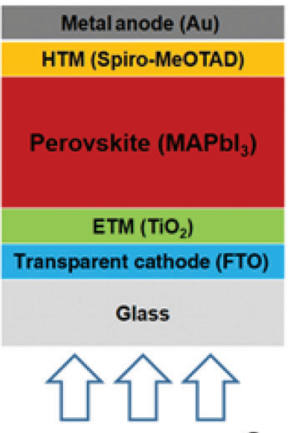

(c) p-i-n planar

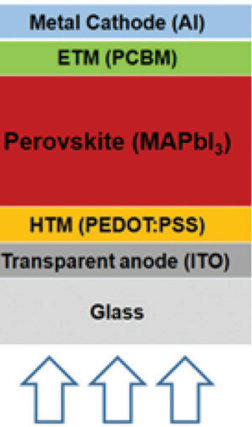

(d) p-i-n mesoscopic

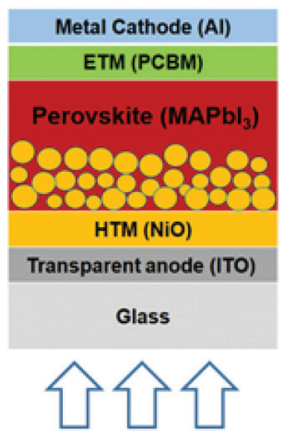

Fig. 6. Schematic of perovskite solar cells with (a) $n-i-p$ mesoscopic, (b) $n-i-p$ planar, (c) $p-i-n$ planar, and (d) $p-i-n$ mesoscopic structures.

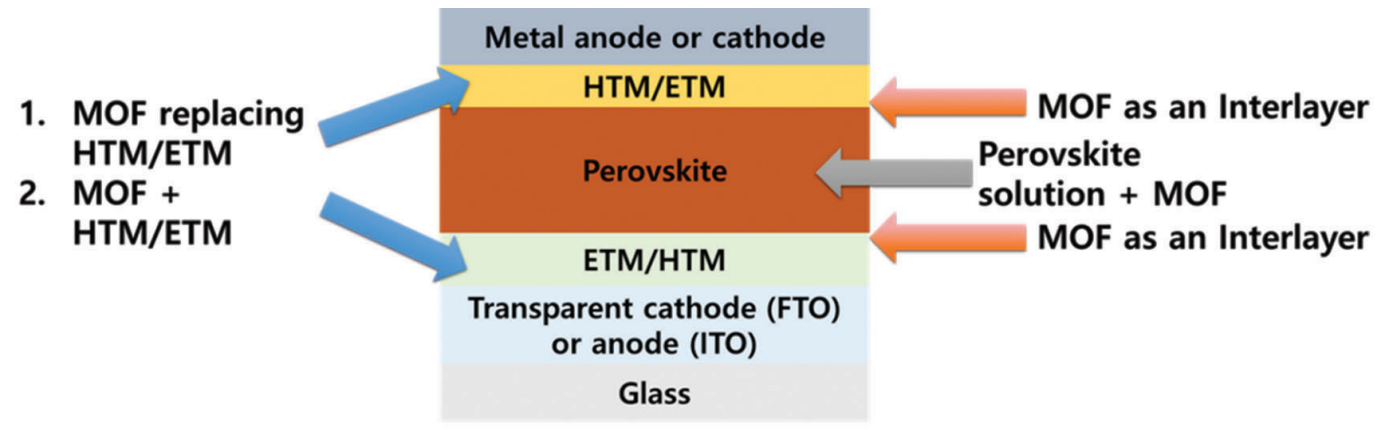

Fig. 7. Schematic of where MOFs can be used in PSCs.

$\mathrm{PSCs}$ 는 단결정 실리콘 태양전지와 비교할 만한 높은 $\mathrm{PCE}$ 를 가지고 있다. 그럼에도 불구하고 장기 안정성 문 제는 $\mathrm{PSCs}$ 의 상용화에 걸림돌이 된다. 일반적으로 페 로브스카이트 필름은 많은 결함과 결정립계(전자/정공 재결합이 발생하는 위치)를 가지고 있기 때문에 장치의 성능을 불안정하게 한다. 따라서 최근 $\mathrm{PSCs}$ 연구자들 은 안정성과 효율성 향상에 연구의 초점을 맞추고 있다 103-104). 무기 이온 ${ }^{105-107)}$, 첨가제 ${ }^{108-110)}$, 새로운 ETL 또는 $\mathrm{HTL}^{111,112)}$, interlayer ${ }^{113,114)}$ 등을 사용하여 결정성을 향 상시키기 위한 연구가 수행되었다.

화학적 및 열적으로 안정한 나노 구조 $\mathrm{MOF}$ 는 $\mathrm{PSCs}$ 에서 매력적인 재료로 상당한 관심을 받고 있다. 안정 성 외에도 $\mathrm{MOF}$ 는 간단한 합성과 용액공정을 통한 증착 이 가능하다는 장점이 있다. 또한 $\mathrm{MOF}$ 는 구성 금속 이 온 및 유기 링커를 제어함으로써 다양한 광전자 특성을
나타낼 수 있기 때문에 PSCs에서도 다양하게 사용될 수 있다. Fig. 7은 PSCs 구조에서 $\mathrm{MOF}$ 의 4가지 응용 방 법을 나타냈다. $\mathrm{MOF}$ 는 훌륭한 전하, 정공 수송 경로가 되며, 필름 품질을 개선하여 전하 재결합을 억제하는데 효과적이다. $\mathrm{PSCs}$ 에서 $\mathrm{MOF}$ 의 다양한 역할을 식별하고 설명하고자 한다.

\subsection{PSCs의 전자 수송 물질로 사용된 MOFs}

태양전지의 전자 수송 물질(ETM)은 높은 carrier mobility를 가져야 하고 그들의 에너지 level은 태양 전 지에 있는 다른 층의 에너지 level과 일치해야 한다. 높 은 비표면적과 적은 결함은 $\mathrm{PCE}$ 를 개선시키는 데 중요 한 역할을 한다. 앞서 말했듯이 $\mathrm{TiO}_{2}$ 는 구조적 안정성 이 우수하고 비용이 저렴하기 때문에 PSCs의 ETM으 로 주로 사용된다 ${ }^{115-117)}$. 그러나 상용 $\mathrm{TiO}_{2}$ 의 밴드 갭은 
(a)

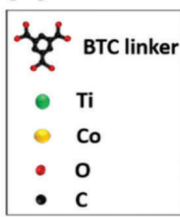

(b)

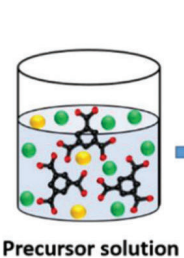

Precursor solution

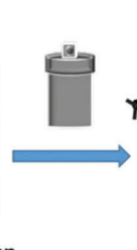

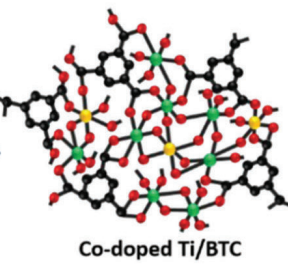

Co-doped Ti/BTC

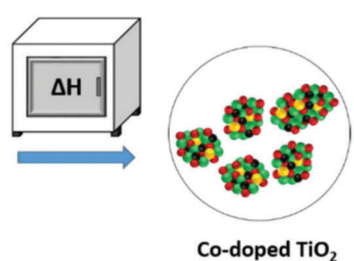

(c)
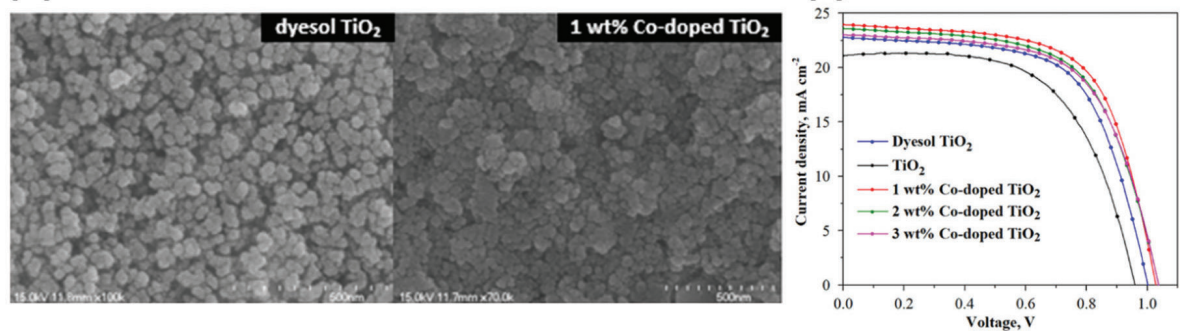

Fig. 8. (a) Schematic of the preparation of Co-doped $\mathrm{TiO}_{2}$ particles (BTC: trimesic acid). (b) SEM images of dyesol $\mathrm{TiO}_{2}$ and $1 \mathrm{wt}$ \% Co-doped $\mathrm{TiO}_{2}$ paste on FTO-coated glass. (c) $\mathrm{J}-V$ curves of the best performing PSCs using dyesol $\mathrm{TiO}_{2}$, undoped $\mathrm{TiO}_{2}$, and $\mathrm{Co}-$ doped $\mathrm{TiO}_{2}$ (1, 2, and 3 wt \%) [118].

약 $3.3 \mathrm{eV}$ 로 자외선 범위에 속한다. 큰 밴드 갭은 전자 를 여기 시키고 주입하는데 어려움을 주고, 전자 수송 을 비효율적으로 만든다. 밴드 갭을 줄이기 위해 반도체 에 금속을 도핑 하는 방법이 제안되고 있다. Nguyen 등 은 용매 열 합성법으로 cobalt(Co)-doped $\mathrm{TiO}_{2} \mathrm{MOF}$ 를 합성하였다 ${ }^{118)}$. $\mathrm{Co}$ 는 $\mathrm{TiO}_{2}$ 의 밴드갭 에너지를 감소시 키며, $\mathrm{TiO}_{2}$ 격자에 $\mathrm{Co}$ 결함 원자가 존재하기 때문에 왜 곡을 촉진한다. $\mathrm{Ti}-\mathrm{MOF}$ 는 $\mathrm{Ti}$ 를 $\mathrm{TiO}_{2}$ 로 변환하기 위해 공기중에서 calcination 했다(Fig. 8 (a)). $1 \mathrm{wt} \% \mathrm{Co}-$ doped $\mathrm{TiO}_{2} \mathrm{MOF}$ 는 dyesol $\mathrm{TiO}_{2}$ 보다 높은 다공성 구 조를 나타내며, 더 나은 광전지 성능을 보여준다(Fig. 8 (b), (c)). Dyesol $\mathrm{TiO}_{2} \mathrm{PSC}$ 의 $\mathrm{PCE}$ 는 $12.32 \%$ 인데 반 해, $\mathrm{Co}$-doped $\mathrm{TiO}_{2} \mathrm{MOF} \mathrm{PSC}$ 는 $15.75 \%$ 의 $\mathrm{PCE}$ 를 나 타내어, $\mathrm{TiO}_{2} \mathrm{MOF}$ 에 $\mathrm{Co}$ 를 도핑하면 $\mathrm{PSC}$ 의 효율 향상 에 도움을 준다는 것을 확인했다. Co의 도핑으로 인해 전하 수송 저항 $\left(\mathrm{R}_{\text {trans }}\right)$ 과 전하 재결합 저항 $\left(\mathrm{R}_{\mathrm{rec}}\right)$ 이 현저 히 감소했으며, 도펀트는 전자 수송을 촉진하고 전자정공 재결합을 완화시키는 역할을 하는 것을 확인했다 (Fig. 8 (d)). 이러한 결과는 $\mathrm{MOF}$ 템플릿의 열분해로 얻 은 내부 및 표면형태와 Co 도핑으로 인한 전자 이동의 개선에 기인한다.

위에서 언급했듯이 일부 연구는 $\mathrm{MOF}$ 와 $\mathrm{TiO}_{2}$ 를 혼합
한 반면, $\mathrm{TiO} 2$ 와 페로브스카이트 층 사이에 $\mathrm{MOF}$ 층을 mesoporous 수송층으로 삽입한 연구도 있다. $\mathrm{TiO} 2$ 층 위에 $\mathrm{ZIF}-8$ 를 코팅하고, 반응 시간에 따른 PSCs의 성 능을 비교했다 ${ }^{119)}$. $\mathrm{ZIF}-8$ 이 존재하는 PSCs의 PCE는 $9.6 \%$ 에서 $12.0 \%$ 로 향상되었고, 최적의 $\mathrm{ZIF}-8$ 코팅을 위한 immersion time은 2 분임을 확인했다. $\mathrm{TiO}_{2}$ 와 페 로브스카이트 층 사이에 위치한 $\mathrm{ZIF}-8 \mathrm{MOF}$ 층은 여기 된 전자의 전달 속도와 $~ 350 \mathrm{~nm}$ 이상의 파장에서 페로 브스카이트 film의 흡광도를 향상시킨다.

$\mathrm{TiO}_{2}$ 이외에도 $\mathrm{ZnO}$ 와 $\mathrm{SnO}_{2}$ 가 ETM으로 널리 사용된 다 ${ }^{120-123)} . \mathrm{ZnO}$ 는 $\mathrm{TiO}_{2}$ 와 유사한 물리적 특성 및 energy level 위치를 가지며 높은 전자 이동성과 구조적 다양성 으로 인해 매력적인 $\mathrm{ETM}$ 이다 ${ }^{124-152)} \mathrm{ZnO}$ 층은 저온 공 정이 가능하여 대량 생산에 유리하고, flexible device 에도 적용될 수 있다 ${ }^{126-128)}$. 그러나 순수 $\mathrm{ZnO}$ 를 기반으 로 하는 $\mathrm{PSC}$ 의 $\mathrm{PCE}$ 는 여전히 $15 \sim 16 \%$ 정도로, $\mathrm{TiO}_{2}$ 또 는 $\mathrm{SnO}_{2}$ 기반의 $\mathrm{PSC}$ 보다 현저히 낮다 ${ }^{129,130)} . \mathrm{ZnO}$ 의 성 능은 제조 공정에서 화학 잔류물이 존재하기 때문에 불 안정하다. 따라서 $\mathrm{ZnO} \mathrm{ETM}$ 의 품질을 최적화하는 것 은 전하 수집을 개선하고 재결합을 감소시켜 $\mathrm{PCE}$ 의 안정성과 효율 향상을 위해 중요하다. $\mathrm{MOF}$-derived porous oxide는 큰 비표면적과 균일한 pore network 


\section{특 집 표 허도연, 김수영}
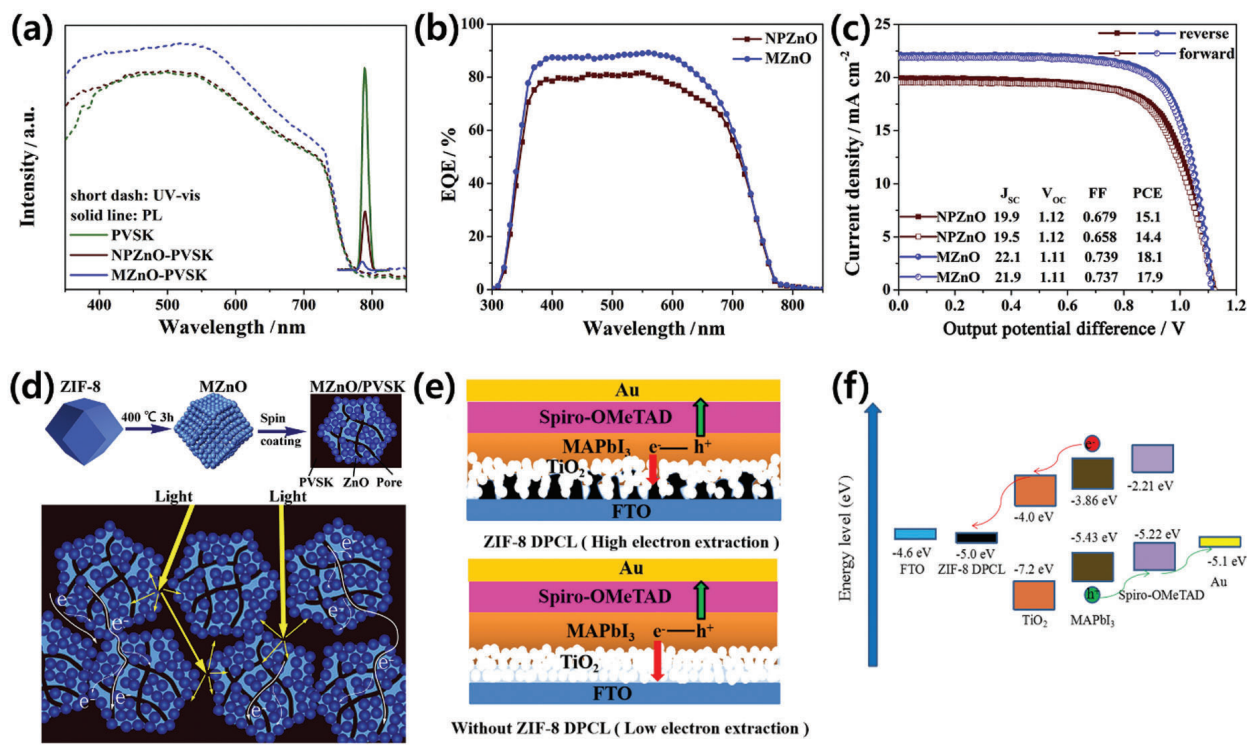

Fig. 9. (a) The absorption and fluorescence spectra of the perovskite films with and without MZnO. (b) EQE curves, and (c) champion cell performance and hysteresis for PSCs with different ETLs. (d) Schematic of the formation of MZnO and its use as an ETL to enhance light harvesting and electron extraction [131]. (e) Schematic of the perovskite solar cell structures with and without the ZIF-8-derived porous carbon layer, and (f) energy level diagram of the ZIF-8 DPCL-based device [132].

를 가지고 있기 때문에 페로브스카이트로의 효과적인 침투를 용이하게 하고, $\mathrm{ETM} /$ 페로브스카이트 사이의 접 촉 면적을 증가시킬 수 있기 때문에 $\mathrm{ZnO} \mathrm{ETM}$ 의 품질 을 최적화하기 위한 훌륭한 후보군이다. Zhang 등은 12 면체 다공성 구조를 갖는 $\mathrm{MOF}$-derived $\mathrm{ZnO}(\mathrm{MZnO})$ 를 $\mathrm{ETM}$ 으로써 사용했다 ${ }^{131)} . \mathrm{MZnO}$ 는 $\mathrm{PL}$ 강도를 억제 하고, 전자 수명을 줄이며, 전하 재결합 저항을 증가시 키고, 트랩 상태의 밀도를 감소시킴으로써 전자 추출 및 전자-정공 재결합 속도를 억제했다 (Fig. 9 (a), (b)). $\mathrm{MZnO}$ 의 도입은 활성 전자 수송 경로를 증가시키고 Jsc 및 $\mathrm{FF}$ 를 증가시킴으로써 순수한 $\mathrm{ZnO}$ 기반 $\mathrm{PSC}(15.1 \%)$ 에 비해 $\mathrm{PCE}(18.1 \%)$ 를 증가시킨다. 저자들은 $\mathrm{MZnO}$ 의 독특한 모양과 큰 내부 기공이 더 높은 광 흡수 밀도를 유도하고 $\mathrm{PSC}$ 의 광학 활용 효율을 효과적으로 개선한다 는 것을 발견했다(Fig. 9 (c), (d)).

ZIF-8 MOF는 n-i-p mesoscopic 구조에서 독자 적인 compact-ETM으로써 연구되었다 ${ }^{132}$ (Fig. 9 (e)). Zhang 등은 polyvinylpyrrolidone (PVP)를 용액 가열 방법으로 입자크기를 조정하여 더 작은 나노 입자를 갖 는 ZIF-8 powder를 합성했다 ${ }^{133)}$. 합성한 ZIF-8 MOF
는 carbonization을 통하여 ZIF-8 derived porous carbon layer(DPCL)로 증착되어 PSCs의 ETL로 사용 됐다. $\mathrm{PSC}$ 에 태양 광이 입사되면 전자는 페로브스카이 트의 conduction band로 여기 된 다음 $\mathrm{TiO}_{2}$ 와 탄소의 conduction band에 주입되고, 마지막으로 FTO 양극 에서 수집된다 (Fig. 9 (f)). FTO의 일함수는 $4.6 \mathrm{eV}$ 이 므로 $5.0 \mathrm{eV}$ 의 일함수를 갖는 $\mathrm{ZIF}-8 \mathrm{DPCL}$ 은 광 여기 동안 전자 주입에 유리하다. $\mathrm{ZIF}-8 \mathrm{DPCL}$ 의 높은 전도 성과 얇은 두께로 인해 전자 수송 속도가 증가될 수 있 기 때문에 PSCs의 PCE가 $14.25 \%$ 에서 $17.32 \%$ 로 향상 되었다.

$\mathrm{ETM}$ 의 중요성은 flexible PSCs에서도 강조된다. $\mathrm{PSCs}$ 는 뛰어난 기계적 유연성으로 인해 웨어러블 장 치 및 통합 태양광 시스템 구축에 적합하다 ${ }^{134,135)}$. 그러 나 공정 온도가 낮아야 하기 때문에 $\mathrm{TiO}_{2}$ 층의 높은 처 리 온도 $\left(>450{ }^{\circ} \mathrm{C}\right)$ 는 flexible PSCs에 적용하기 어렵 다. Ryu 등은 상온에서 나노 결정 MIL-125 (Ti) (nTi$\mathrm{MOF}$ )를 ETL로 적용하여 flexible PSCs를 제작하는데 성공했다 ${ }^{136)}$. Tauc plot에서 nTi-MOF의 밴드 갭(3.7 $\mathrm{eV})$ 이 $\mathrm{TiO}_{2}$ 나노 입자 $(3.55 \mathrm{eV})$ 보다 더 넓은 것을 확인 
했다. 또한 $\mathrm{nTi}-\mathrm{MOF}$ 의 conduction band minimum (CBM)과 $\mathrm{VBM}$ 은 각각 -4.12 와 $7.82 \mathrm{eV}$ 이며 $\mathrm{TiO} 2$ 나 노 입자는 $-3.98,-7.53 \mathrm{eV}$ 로 계산되었다. 페로브스 카이트 층의 $\mathrm{CBM}$ 이 $-3.8 \mathrm{eV}$ 인 것을 고려하면, $\mathrm{nTi}-$ $\mathrm{MOF}$ 는 ETL로 적합하다. $\mathrm{nTi}-\mathrm{MOF}$ ETL $(4.46 \times$ $\left.10^{-5} \mathrm{~S} \mathrm{~cm}^{-1}\right)$ 의 전기 전도도는 $\mathrm{TiO}_{2} \mathrm{ETL}\left(6.38 \times 10^{-5}\right.$ $\left.\mathrm{S} \mathrm{cm}^{-1}\right)$ 의 전기 전도도보다 약간 낮았으며 필름 두께 에 크게 영향을 받는다. nTi-MOF ETL의 전도도는 막 두께가 20에서 $60 \mathrm{~nm}$ 로 증가함에 따라 $4.46 \times 10^{-5}$ $\mathrm{S} \mathrm{cm}^{-1}$ 에서 $2.32 \times 10^{-5} \mathrm{~S} \mathrm{~cm}^{-1}$ 로 크게 감소했다. 그 러나 [6,6]-phenyl-C61-butyric acid (PCBM) 증착 후 $\mathrm{nTi}-\mathrm{MOF}$ ETL의 전도성은 $1.09 \times 10^{-4} \mathrm{~S} \mathrm{~cm}^{-1}$ 까 지 크게 향상되었다. 저자들은 $\mathrm{PCBM}$ 을 코팅함으로써 $\mathrm{nTi}-\mathrm{MOF}$ ETL 내에 미세균열이 채워져 전기 경로를 제공할 수 있으며, 그에 따라 전도성이 향상되고 페로브 스카이트와 ITO 사이의 직접적인 접촉을 억제한다고 주 장한다. 이것은 $\mathrm{PSCs}$ 의 태양광 성능에서 직접적으로 확 인할 수 있다. $\mathrm{PCBM}$ 이 없는 nTi-MOF rigid PSCs의 PCE는 16.41\%인 반면, nTi-MOF/PCBM rigid PSCs 의 $\mathrm{PCE}$ 는 $18.94 \%$ 로 향상된 결과를 보였다. 또한, $\mathrm{nTi}-$ $\mathrm{MOF}$ flexible PSCs 의 $\mathrm{PCE}$ 는 $17.43 \%$ 로, rigid $\mathrm{PSC}$ 의 $\mathrm{PCE}$ 와 많은 차이가 없었으며 내구성은 최대 700회 굽 힘 주기로 유지되어 $15.43 \%$ 의 $\mathrm{PCE}$ 를 나타냈다. 이러한 결과는 nTi-MOF가 $\mathrm{PSC}$ 에서 매우 유연하고 고성능의 $\mathrm{PSCs}$ 를 설계할 때 큰 잠재력을 가지고 있는 것을 시사 한다.

\subsection{PSCs의 정공 수송 물질로 사용된 MOFs}

$\mathrm{PSCS}$ 에서 전자 수송 물질(HTM)은 (i ) 페로브스카이 트 층과 캐소드 전극 $(\mathrm{Al}, \mathrm{Ag}$ or $\mathrm{Au})$ 사이의 장벽을 제 공하고, (ii) cathode로의 전자 전달을 차단하고 (iii) 결 과적으로 접촉면에서 광 여기 된 electron-hole pair 의 재결합을 억제하는 역할을 한다. 따라서 $\mathrm{PSC}$ 의 $\mathrm{PCE}$ 와 장기안정성은 $\mathrm{HTM}$ 에 크게 의존한다. 고효율 $\mathrm{PSC}$ 를 얻기 위해 우수한 열 및 광화학적 안정성, 우수한 전 도성, 높은 정공 이동성을 가진 $\mathrm{HTM}$ 을 사용해야 한 다. 특히 HTM은 페로브스카이트 물질로부터 HTL까지
효과적인 정공 주입을 위해 페로브스카이트의 lowest occupied molecular orbital (LUMO)와의 매칭을 위 한 적절한 에너지 레벨을 가져야한다 ${ }^{138,139)}$. 가장 일반 적인HTM 중 하나는 $2,2,7,7^{\prime}-$ Tetrakis[N,N-di(4methoxyphenyl)amino]-9,9'-spiro-bifluorene (spiro-OMeTAD)이다. 처음에는 액체 전해질을 대체 하기위해 $\mathrm{PSCS}$ 에 도입되어 최대 $9.7 \%$ 의 고효율을 달 성했다 ${ }^{140)}$. 그러나 낮은 고유 정공 이동도와 전도성은 spiro-OMeTAD의 사용을 제한한다. 따라서 lithium bis(trifluoromethanesulfonyl)imide (Li-TFSI) 와 tetra-tert-butylpyridine (TBP)가 전도성을 향상시 키기 위한 첨가제로 사용된다 ${ }^{141,142)}$. Li-TFSI는 spiro$\mathrm{OMeTAD}$ 를 직접 산화시킬 수 없기 때문에 산화 정도를 제어할 장치가 필요하다 ${ }^{143)}$. Spiro-OMeTAD를 직접 산 화시키고 $\mathrm{PSCS}$ 의 $\mathrm{PCE}$ 를 향상시키는 다양한 첨가제가 개발되었다 ${ }^{144-148)}$. 그러나 첨가제의 사용은 낮은 수율과 낮은 안정성을 갖는 여러 공정을 거쳐야하기 때문에 저 렴고 간단한 기술로 합성 가능한 소재를 개발하는 것이 중요하다.

Indium oxide는 indium의 전도성이 우수하 여 유기 전자 소자의 p-type 재료로 사용된다. $\left[\mathrm{In}_{2}\right.$ (phen) $\left.{ }_{3} \mathrm{Cl}_{6}\right] \cdot \mathrm{CH}_{3} \mathrm{CN} \cdot 2 \mathrm{H}_{2} \mathrm{O}$ (In2)은 band alignment engineering을 통해 HTM의 첨가제로 $\mathrm{Li}$ 등에 의해 소개됐다 ${ }^{149}$. Fig. 10 (a)는 Spiro-OMeTAD 에 In2를 첨가한 것과 첨가하지 않은 페로브스카이트 필 름의 UV-vis 흡수 스펙트럼을 보여준다. 스펙트럼의 모양은 320 800 nm에서 유사하다. 그러나 $\operatorname{In} 2$ 를 첨 가하면 320 540 nm에서 흡수도가 향상되었다. HTM 과 $\mathrm{HTM} / \mathrm{In} 2$ 필름의 전계 방출 주사 전자 현미경 $(\mathrm{FE}-$ $\mathrm{SEM}$ ) 이미지에서 $\mathrm{HTM} / \mathrm{In} 2$ 필름은 핀홀이 적고 많 은 큐브로 균일하게 덮여 있는 것을 볼 수 있다(Fig. 10 (b)). 핀홀은 back contact의 금속이 페로브스카이트에 도달할 수 있는 통로로 이용되기 때문에 PSCs의 불안정 성을 초래한다 ${ }^{150,151)}$. 따라서 $\mathrm{In} 2$ 의 첨가는 고밀도 $\mathrm{HTL}$ 을 제공하고, $\mathrm{Au}$ 가 전체 $\mathrm{PSCs}$ 구조로 확산되는 것을 방 지하는 버퍼 역할을 한다. 또한 In2는 페로브스카이트의 광 흡수를 개선하여 PSCs의 특성 (Jsc, $\mathrm{Voc}, \mathrm{FF}, \mathrm{PCE}$ ) 

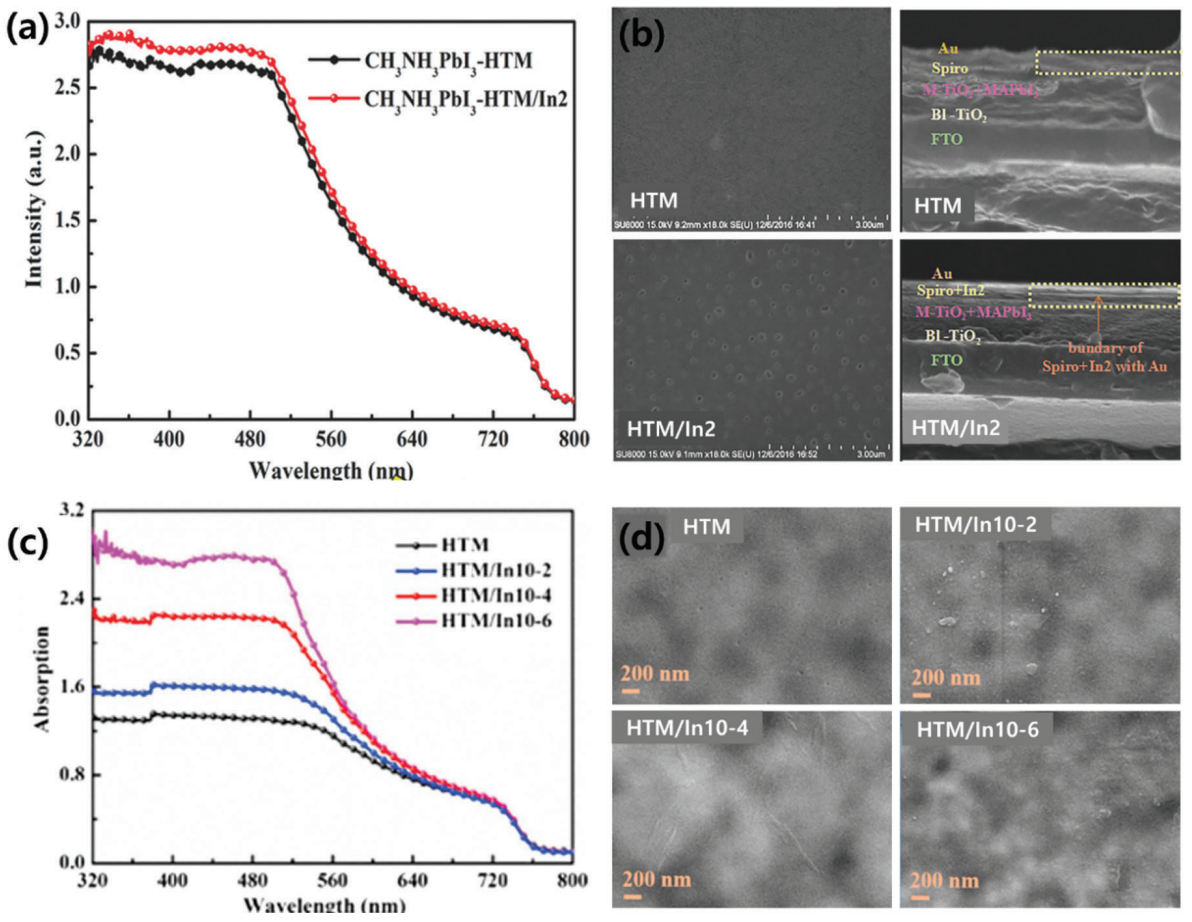

Fig. 10. (a) UV-vis absorption spectra for the HTM with and without In2 and (b) top view SEM images of films with and without In2 [149]. (c) The UV-vis absorption spectra of the HTM with different amounts of In10 and (d) top view SEM images of HTM, HTM/In10-2, HTM/In10-4, and HTM/In10-6 [152].

을 향상시키는 역할을 한다. 특히 $\mathrm{PCE}$ 는 $12.8 \%$ 에서 $15.8 \%$ 로 향상되었다.

$\mathrm{Li}$ 등은 $\left[\operatorname{In}_{0.5} \mathrm{~K}(3-\mathrm{qlc}) \mathrm{Cl}_{1.5}\left(\mathrm{H}_{2} \mathrm{O}\right)_{0.5}\right]_{2 \mathrm{n}}$, ( $\left.\operatorname{In} 10\right)$ 을 추가 로 합성하여 spiro-OMeTAD의 첨가제로 사용했다 ${ }^{152}$. $\mathrm{In} 10$ 이 첨가될 때 spiro-OMeTAD 용액의 색상이 밝은 노란색에서 적갈색으로 변하게 되는데, 이것은 spiro$\mathrm{OMeTAD}$ 의 산화를 나타낸다. Fig. 10 (c)에서 볼 수 있 듯이 In10를 첨가하면 300 500 nm 사이의 UV-vis 흡수 스펙트럼이 향상되었다. In10의 첨가량이 증가할 수록 전체적인 흡수도가 증가하지만, In10의 첨가량이 과하면 필름이 덜 균질해지고, 표면에 덩어리가 생겨 새 로운 트랩 상태로 작용하여 $\mathrm{PSCs}$ 의 성능 저하의 원인 이 된다(Fig. 10 (d)). 적절한 양의 In10은 PSCs의 광 응 답을 개선하는 데 도움이 되며, In10이 없는 것에 비해 $\mathrm{PSCs}$ 의 PCE가 $20 \%$ 이상 향상되었다.

Dong 등은 polyoxometalate@MOF (POM@MOF; $\left[\mathrm{Cu}_{2}(\mathrm{BTC})_{4 / 3}\left(\mathrm{H}_{2} \mathrm{O}\right)_{2}\right]_{6}\left[\mathrm{H}_{3} \mathrm{PMo}_{12} \mathrm{O}_{40}\right]_{2}$ or POM@ $@ \mathrm{Cu}^{-}$
$\mathrm{BTC})$ 를 $\mathrm{HTM}$ 의 도펀트로 사용했다 ${ }^{153)}$. $\mathrm{POM} @ \mathrm{MOF}$ 는 spiro-OMeTAD의 산화를 제어하고, HTL의 안정성을 향상시킬 수 있다. POMs는 metal oxo-cluster의 일종 으로, 높은 전자 수용성과 산화 잠재력을 가지고 있다. $\mathrm{Cu}-\mathrm{BTC} \mathrm{MOF}$ 와 고체 나노 입자의 나노 다공성 구조는 $\mathrm{HTL}$ 의 수분 안정성을 향상시켜 PSCs의 장기 성능을 향 상시킨다. Fig. 11 (a)는 POM@MOF를 사용한 PSCs와 사용하지 않은 PSCs를 한달에 걸친 안정성 테스트를 한 후의 SEM 이미지이다. $\mathrm{POM} @ \mathrm{MOF}$ 를 사용하지 않은 $\mathrm{PSCS}$ 에서는 명백한 균열이 형성되지만, $\mathrm{POM} @ \mathrm{MOF}$ 를 사용한 필름은 균일한 surface coverage를 유지했다. 페로브스카이트 필름의 안정성은 $\mathrm{PSCs}$ 의 성능과 직접 적인 관련이 있다. $\mathrm{POM} @ \mathrm{MOF}$ 를 도핑함으로써 $\mathrm{PSCs}$ 의 $\mathrm{PCE}$ 는 $20.21 \%$ 에서 $21.44 \%$ 로 향상되었고, 주변환경 에서 장기간 보관한 후 초기 $\mathrm{PCE}$ 값의 약 $90 \%$ 를 유지 하는 눈이 띄는 결과를 보였다(Fig. 11 (b)).

Spiro-OMeTAD는 비교적 캐리어 전달 능력이 낮 


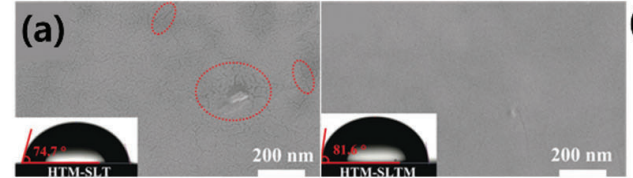

(b)
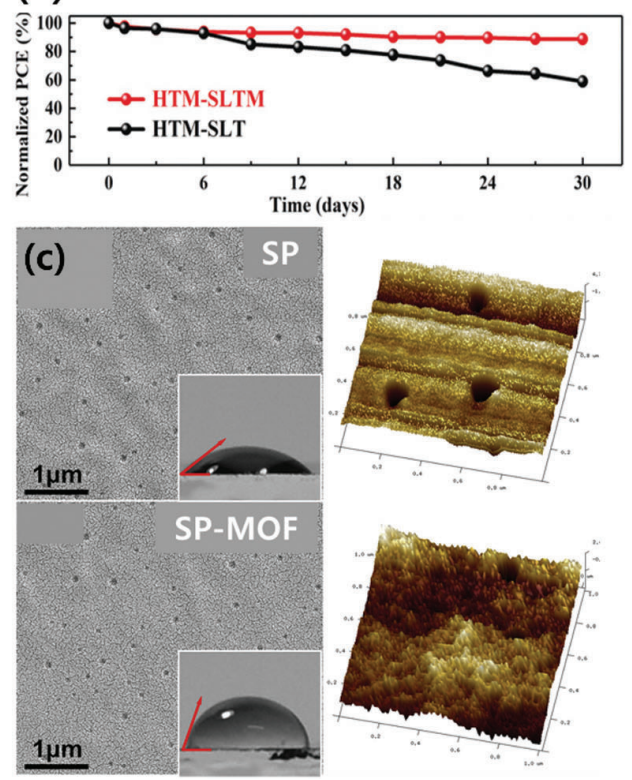

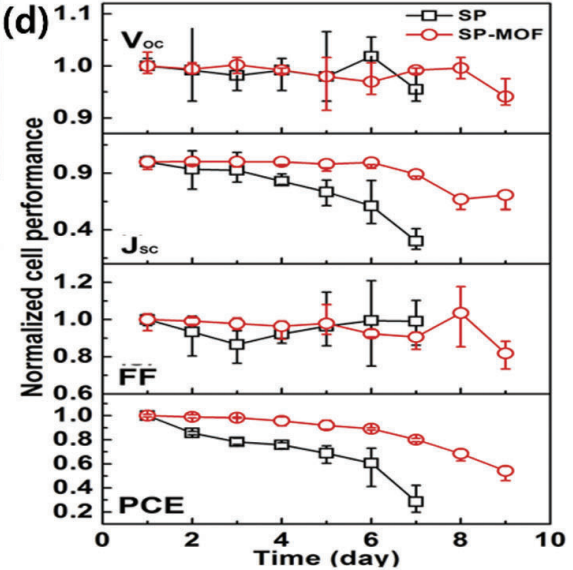

(e)

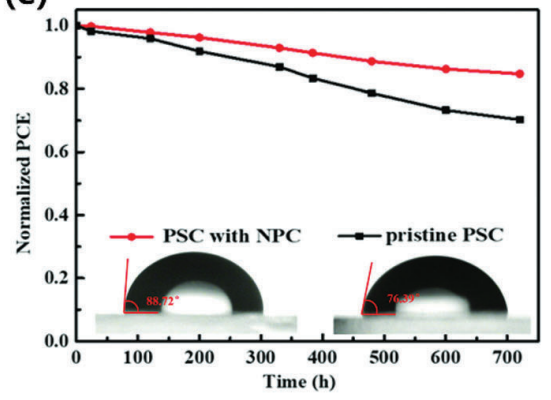

Fig. 11. (a) SEM images of the HTM-SLT- and HTM-SLTM-based PSCs after long-term stability testing for one month; red ovals highlight cracks (insets: water contact angle test). (b) Normalized PCEs over time [153]. (c) SEM surface images (insets: hydrophily) and 3D AFM profiles for SP and SP-MOF samples. (d) The typical J-V curves of PSCs with SP and SP-MOF HTLs over time, in a wet environment [160]. (e) Stability measurements for the pristine PSCs and PSCs with NPC (insets: water contact angles) [161].

고 내습성이 좋지 않기 때문에 spiro-OMeTAD를 대체 할 수 있는 무기 $\mathrm{HTM}$ 이 연구되고 있다. $\mathrm{NiO}, \mathrm{Cu}_{2} \mathrm{O}$, $\mathrm{MoO}_{3}, \mathrm{VO}_{\mathrm{x}}$ 와 같은 금속 산화물이 HTM으로 사용될 수 있으며, 무기 HTM은 수분이 device로 침투하는 것을 방지하고 장치의 안정성을 향상시켰다 ${ }^{154,155)}$. 특히, $\mathrm{NiO}$ 는 낮은 공정 비용, 우수한 정공 추출 특성, 우수한 열과 화학적 안정성, deep valence band를 가지는 특성으 로 $\mathrm{p}$-타입 무기 HTM으로 주목받고 있다. 그러나 $\mathrm{NiO}$ 기반의 PSCs의 효율은 spiro-OMeTAD 기반의 PSCs 보다 여전히 낮다. 그 이유는 $\mathrm{NiO}$ 의 낮은 전도성 및 표 면 결함 때문인이다. 페로브스카이트 계면 근처에 정 공 축적이 수반되는 낮은 전도도는 hole-electron pair 의 재결합 가능성을 높이고 효율적인 전하 수집이 감소 되기 때문에 낮은 효율이 수반된다 ${ }^{156)}$. Hazeghi 등은
$\mathrm{NiO}$ 보다 높은 전기 전도도를 갖는 $\mathrm{CuO}$ 와 $\mathrm{NiO}$ 를 합성 하여 홀 추출력 향상, $\mathrm{NiO}$ 의 트랩 밀도 감소, 페로브스 카이트/HTL 계면에서의 재결합 속도를 억제하여 $\mathrm{NiO}$ 기반의 PSCs의 효율을 향상시키는 데 성공했다 ${ }^{157)}$. 기 존 $\mathrm{NiO} \mathrm{HTL}$ 을 사용한 $\mathrm{PSCs}$ 의 $\mathrm{PCE}$ 는 8.58\%인 반면, core shell $\mathrm{CuO} @ \mathrm{NiO}$ 를 $\mathrm{HTL}$ 로 사용한 PSCs 의 $\mathrm{PCE}$ 는 $10.11 \%$ 였다. $\mathrm{CuO} @ \mathrm{NiO} \mathrm{HTL}$ 기반의 PSC는 spiro$\mathrm{OMeTAD}$ HTL 기반의 PSCs 보다는 낮은 $\mathrm{PCE}$ 를 나타 냈지만, 안정성 테스트에서 탁월한 장기 안정성을 보여 주었다. $\mathrm{NiO}$ 와 $\mathrm{CuO} @ \mathrm{NiO} \mathrm{HTL}$ 기반의 PSC는 1920시 간 (80일) 후에 각각 초기 효율의 52 및 $60 \%$ 이상을 유 지하는 반면, 같은 조건에서 spiro-OMeTAD HTL 기 반의 PSC는 1248 시간 (52일) 후에 초기 효율의 $31.74 \%$ 만을 유지했다. 이러한 결과는 spiro-OMeTAD를 $\mathrm{MOF}$ 
를 활용한 $\mathrm{NiO} \mathrm{HTM}$ 으로 대체하여 더 나은 장기 안정 성을 가진 유망한 PSCs를 제작할 수 있음을 시사한다.

금속 도핑은 $\mathrm{PSCs}$ 에서 $\mathrm{HTL}$ 성능을 최적화하는 또 다른 효과적인 방법이다. 도펀트 중에서 $2 \mathrm{D}$ 나노 물질 은 특수한 평면 이동 운동과 강한 공유결합과 같은 고유 한 속성 덕분에 높은 전기 전도성을 가진 물질로 주목받 고 있다 ${ }^{158)}$. 특히, $\mathrm{Cu}-\mathrm{BHT}(\mathrm{BHT}=$ benzenehexathiol) 의 $2 \mathrm{D} \mathrm{MOF}$ 는 높은 전도성과 투과율을 보였으며 ITO 를 대체할 수 있다 ${ }^{159)}$. 이처럼 $2 \mathrm{D} \mathrm{MOF}$ 는 전도성 물질 로써 충분한 자격을 갖추었고, $\mathrm{HTM}$ 물질에 $2 \mathrm{D} \mathrm{MOF}$ 를 도핑한 연구가 수행되었다. Huang 등은 $2 \mathrm{D} \mathrm{Pb}-\mathrm{MOF}$ hexagon sheet를 성공적으로 합성하고 PSCs에서 HTM 으로 사용하기 위해 spiro-OMeTAD 용액과 혼합했다 ${ }^{160)}$. $2 \mathrm{D} \mathrm{Pb}-\mathrm{MOF}$ 의 첨가로 인한 표면 특징은 $\mathrm{SEM}$ 에서 는 차이를 구분할 수 없지만, 첨가한 sample(0.765)과 하지 않은 sample(1.58)의 root-mean-square (RMS) 거칠기 값은 확연히 줄어든 것을 확인할 수 있다(Fig. 11 (c)). 또한, pristine HTL과 $\mathrm{Pb}-\mathrm{MOF} \mathrm{HTL}$ 의 소수 성을 조사한 결과, 습윤각이 각각 $39^{\circ}$ 및 $71^{\circ}$ 로 측정되 었다. 일반적으로 $\mathrm{RMS}$ 가 클수록 습윤각이 커지는데, $\mathrm{Pb}-\mathrm{MOF}$ 샘플의 높은 소수성은 거칠기보다는 재료의 성분 때문이라고 추론할 수 있다. $\mathrm{Pb}-\mathrm{MOF}$ 를 사용하지 않은 PSCs의 초기 효율은 $10.53 \%$ 였고 9 일 후 초기값 의 $28 \%$ 만 남아있는 반면, $\mathrm{Pb}-\mathrm{MOF}$ 를 사용한 $\mathrm{PSC}$ 는 9 일 후에도 초기효율인 $13.17 \%$ 의 $54 \%$ 를 유지했다(Fig. 11 (d)). 따라서 이러한 결과를 통해 Pb-MOF HTM 사 용시 $\mathrm{PSCs}$ 의 안정성 및 $\mathrm{PCE}$ 가 향상되는 것을 알 수 있 다. $\mathrm{PSCs}$ 의 안정성 향상시키기 위한 또 다른 $2 \mathrm{D} \mathrm{MOF}$ 재료는 보조 첨가제로 사용되는 2D graphitic N-rich porous carbon (NPC)이다 ${ }^{161)}$. NPC는 spiro-OMeTAD 의 첨가제로 사용되는 lithium salt의 응집 및 결함을 감 소시켜 필름 품질을 최적화하여 정공 추출 및 이동을 신 속하게 한다. 또한, $\mathrm{NPC}$ 의 고유한 다공성 및 소수성은 $\mathrm{Li}^{+}$및 anode 금속의 투과를 제한하여 수분이 HTL 및 페로브스카이트 층에 침입하는 것을 방지할 수 있기 때 문에 PSC의 안정성을 향상시킨다(Fig. 11 (e)).

\section{3. 중간층으로 사용된 MOFs 물질}

페로브스카이트 필름 자체도 $\mathrm{PSCs}$ 의 성능, 안정성 및 재현성에 영향을 미친다다). 이러한 관점에서 결정성 이 높은 고품질의 페로브스카이트 필름 얻기 위한 연구 가 수행되었다 ${ }^{163-166)}$. 페로브스카이트의 성장 및 핵 생 성을 조작하여 고품질의 페로브스카이트 필름을 얻을 수 있으며, 이 접근법은 두 가지 측면으로 나눌 수 있다. 한 가지 측면은 페로브스카이트 전구체 용액을 증착 할 때 용매 공학을 통해 결정성이 높은 매우 균일한 페로 브스카이트 박막을 얻는 것이다 ${ }^{167)}$. 또 다른 측면은 페 로브스카이트와 ETL 사이의 계면 공학으로 결정 성장 을 제어하고 필름 품질을 향상시켜 PSCs의 성능을 향상 시키는 것이다. 따라서 중간층은 $\mathrm{PSCs}$ 의 효율과 안정 성 향상에 중요한 역할을 한다 ${ }^{168)} \cdot \mathrm{Sb}_{2} \mathrm{~S}_{3}{ }^{169)}$, plasmonic $\mathrm{Au}$ nanoparticles ${ }^{170)}, \mathrm{MgO}^{171)}, \mathrm{Au} @ \mathrm{SiO}_{2}{ }^{172)}$ 은 $\mathrm{PSCs}$ 의 hysteresis를 감소시키고 장치의 안정성을 향상시키기 위해 페로브스카이트와 $\mathrm{TiO}_{2}$ 층 사이의 중간층으로 사 용된다. 그러나 $\mathrm{Sb}_{2} \mathrm{~S}_{3}$ 를 제외하고, 이러한 물질의 합성 에는 오랜 시간과 고온이 필요하다. 따라서 $\mathrm{MOF}$ 를 중 간층으로 적용하는 것도 $\mathrm{PSCs}$ 에서 중요한 도구이다.

Wei 그룹은 ZIF-8을 mesoporous $(\mathrm{mp})-\mathrm{TiO}_{2}$ 와 페 로브스카이트 층 사이의 중간층으로 처음 사용했다 ${ }^{173)}$. Fig. 12 (a)는 ZIF-8 층과 페로브스카이트 필름 사이 의 상호 작용의 개략도를 보여준다. ZIF-8층이 $\mathrm{mp}-$ $\mathrm{TiO}_{2}$ 필름의 표면에 코팅되면 이후에 증착 된 페로브스 카이트 필름의 결정화 초기단계에서 결정 성장을 지지 하는 추가 scaffold 역할을 할 수 있다 ${ }^{174)}$. ZIF-8의 결 정구조에서 methyl group은 페로브스카이트의 halide anion과 수소결합을 형성하여 페로브스카이트 필름과 기판 사이의 응집력을 향상시킬 수 있다. 따라서 최적의 ZIF-8 양은 인접한 페로브스카이트 입자와 효과적으 로 결합되어 페로브스카이트 입자 크기와 거칠기를 줄 이고 $\mathrm{mp}-\mathrm{TiO}_{2}$ 필름 표면에 고품질의 광 수확 층을 형 성할 수 있다(Fig. 12 (b)). mp- $\mathrm{TiO}_{2} / \mathrm{ZIF}-8 \mathrm{PSCs}$ 는 $16.99 \%$ 의 $\mathrm{PCE}$ 를 나타내어 $\mathrm{mp}-\mathrm{TiO}_{2} \mathrm{PSCs}(14.75 \%)$ 보 다 높은 $\mathrm{PCE}$ 를 나타냈다. $\mathrm{ZIF}-8$ 중간층은 계면에서 광 생성 캐리어의 재결합을 억제하고 전하 추출을 개선할 


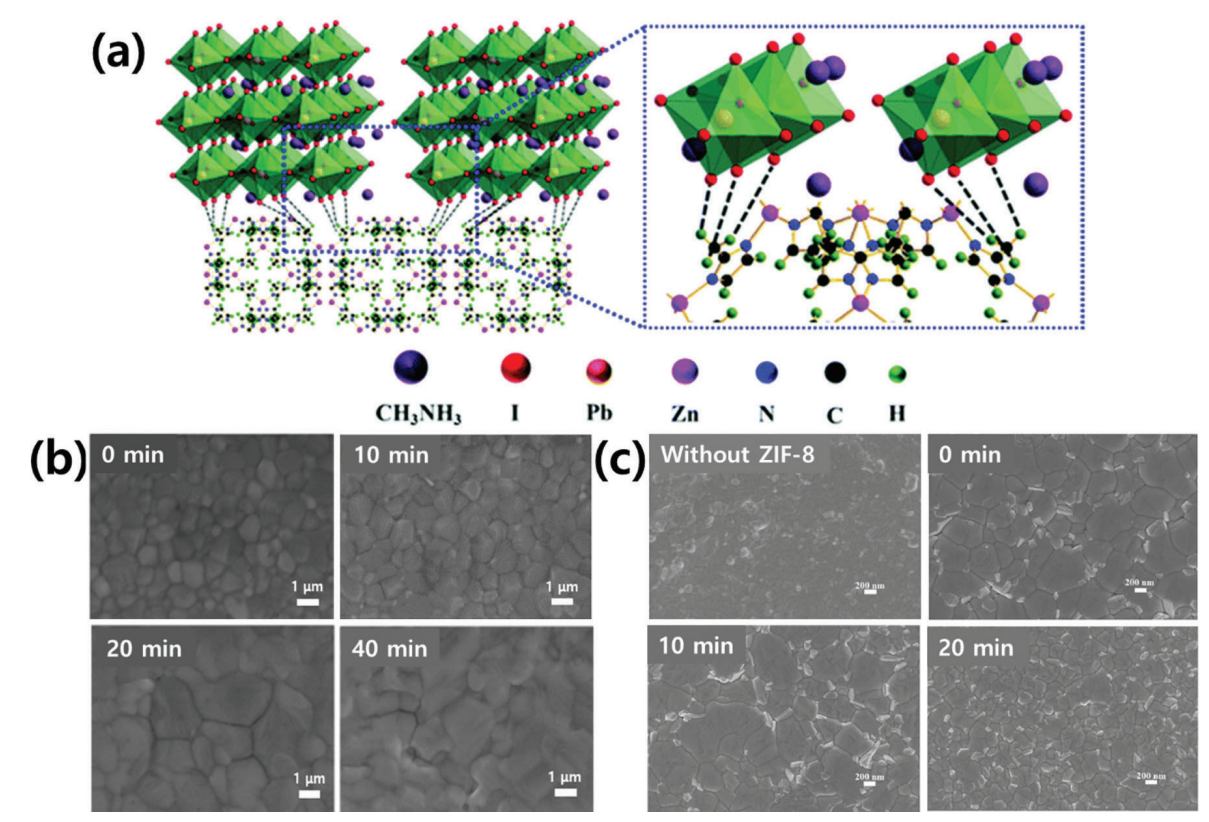

Fig. 12. (a) Schematic of two neighboring grain structures crosslinked by the methyl groups in ZIF-8 [173]. (b) SEM images of the MAPbl${ }_{3}$-based layer formed on the surface of $\mathrm{mp}-\mathrm{TiO}_{2}$ with different $\mathrm{ZIF}-8$ coating times: $0,10,20$, and 40 min [174]. (c) SEM images of the perovskite films formed on $\mathrm{c}-\mathrm{TiO}_{2}$ and $\mathrm{C}-\mathrm{TiO}_{2} / \mathrm{ZIF}-8$ layers with different $\mathrm{ZIF}-8$ synthesis times; 0,10 , and $20 \mathrm{~min}$ followed by ultrasonic vibration for $3 \mathrm{~min}$ [175].

수 있는 역할을 한다는 것을 확인했다.

이와 유사하게 Eslamian 그룹은 compact(cp)- $\mathrm{TiO}_{2}$ 와 페로브스카이트 층 사이에 $\mathrm{mp}-\mathrm{TiO}_{2}$ 대신 $\mathrm{ZIF}-8$ 을 중간층으로 사용하여 $16.8 \%$ 의 $\mathrm{PCE}$ 를 보이는 $\mathrm{PSCs}$ 를 제작하였다 ${ }^{175)}$. Fig. 12 (c)에서 볼 수 있듯이, ZIF-8을 중간층으로 사용하면 페로브스카이트의 입자 크기가 크 게 증가했다. $\mathrm{ZIF}-8$ 중간층으로 인해 입자의 크기가 커 지면 결함에 의해 포획되는 전하 캐리어 수가 줄어들고, 페로브스카이트와 ZIF-8 사이의 밴드 정렬은 표면 결 함 트랩으로부터 엑시톤을 보호하는 에너지 장벽을 생 성한다. 즉 $\mathrm{ZIF}-8$ 은 $\mathrm{mp}-\mathrm{TiO}_{2}$ 를 대체할 수 있으며, 저 온에서 쉽게 합성할 수 있는 장점이 있다.

ETL과 페로브스카이트 층 사이의 중간층으로 $\mathrm{MOF}$ 를 사용하는 다른 그룹과 달리 Nguyen 등은 $n-i-p$ 구 조의 페로브스카이트 층과 $\mathrm{HTL}$ 사이에 $\mathrm{MOF}$ 를 적용했 다 ${ }^{176)}$. 중간층은 페로브스카이트/HTL 계면에서 에너지 손실을 최소화하고 두 층사이의 에너지 레벨 불일치를 조정할 수 있다. 또한, 페로브스카이트의 conduction band에서 HTL의 valance band로 이동하는 전자를 억 제할 수 있다 ${ }^{177,178)}$. 페로브스카이트와 spiro-OMeTAD 층 사이의 중간층으로써 $\mathrm{NiO}$ 의 효과가 입증됐다 ${ }^{179)}$. $\mathrm{NiO} @ \mathrm{C}$ 를 합성하여 $\mathrm{NiO}$ 중간층의 효능을 개선하는데 사용했다. $\mathrm{NiO} @ \mathrm{C}$ 중간층은 활성층에서 전자-정공 쌍 의 재조합을 지연시키고 전하 수송 저항을 감소시켜 결 과적으로 $\mathrm{PSCs}$ 의 $\mathrm{PCE}$ 를 $13.79 \%$ 에서 $15.78 \%$ 로 증가시 키는 것으로 밝혀졌다.

\section{4. 하이브리드 페로브스카이트-MOFs}

계속 강조하겠지만, $\mathrm{PSCs}$ 연구에서 가장 중요한 점은 효율과 안정성을 개선하는 것이다. PSCs의 안정성은 주 로 페로브스카이트 층에 존재하는 고유한 결함과 관련 이 있다. $\mathrm{PSCs}$ 는 $\mathrm{H}_{2} \mathrm{O}$ 와 페로브스카이트 구성 이온 사 이에 수소결합이 형성되어 격자가 붕괴되기 때문에 습 기에 취약하다 ${ }^{180,181)}$. 더욱이 강한 열/광 응력은 iodide 산화를 일으켜 $\mathrm{I}_{2}$ 형성과 $\mathrm{CH}_{3} \mathrm{NH}_{2}$ 의 휘발을 일으켜 재 료의 열화를 초래한다 ${ }^{181,182)}$. 이전 섹션에서 우리는 다공 
(a)

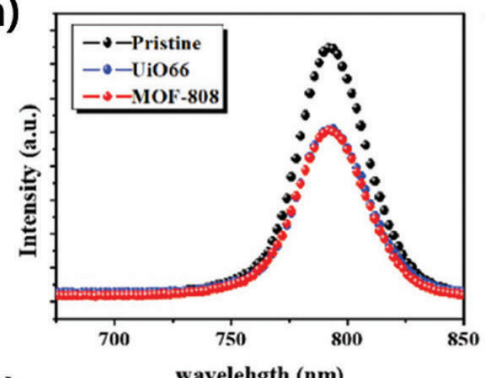

(c)

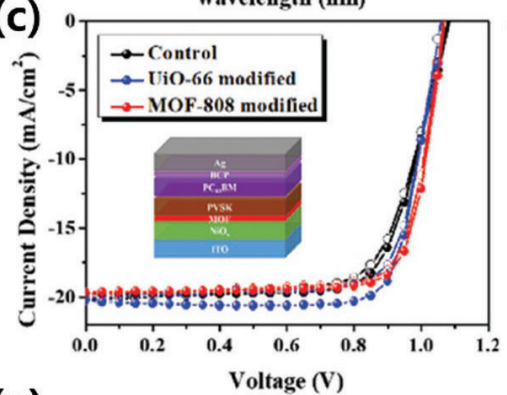

(e)

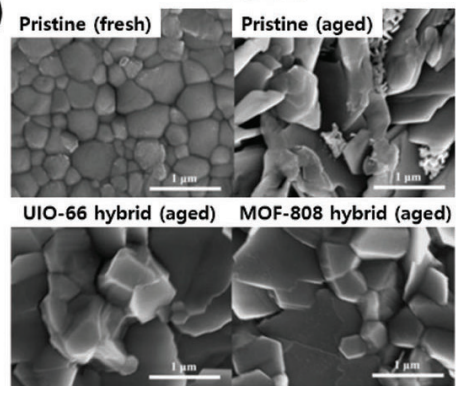

(b)
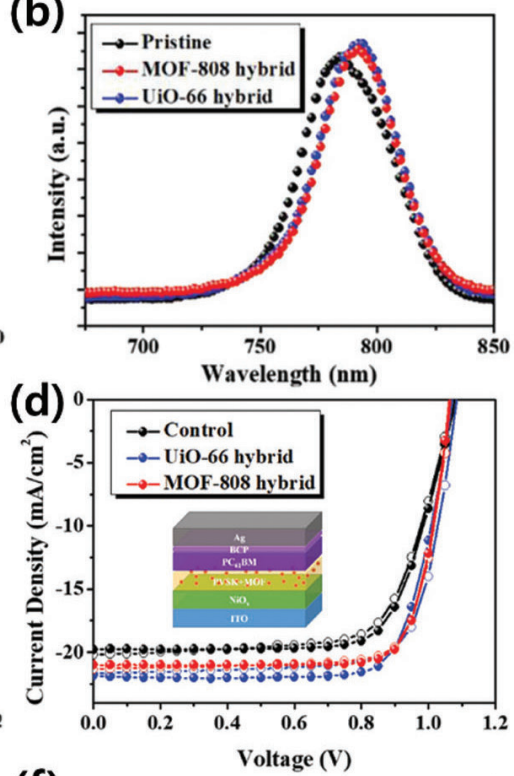

(f)

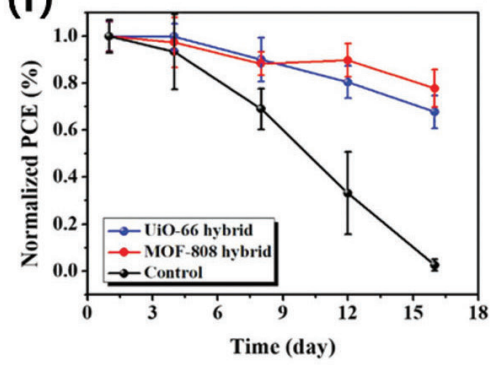

Fig. 13. PL spectra of (a) bilayer MOF/perovskite films, and (b) hybrid P-MOF films. The $J-V$ curves of (c) the PSC employing MOF as a bilayer and (d) the hybrid P-MOF PSC. (e) SEM images of the films after 30 days of aging. (f) The PCEs of the fabricated devices as a function of storage time in ambient air $\left(25^{\circ} \mathrm{C}\right.$ and $\left.\mathrm{RH}: 60 \pm 5 \%\right)$ [183].

성 scaffold 중간층으로 MOF를 사용하여 페로브스카이

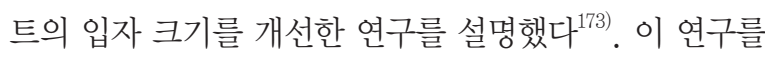
기반으로 페로브스카이트와 $\mathrm{MOF}$ 를 혼합하여 하이브리 드 페로브스카이트- $\mathrm{MOF}(\mathrm{P}-\mathrm{MOF}) \mathrm{PSCs}$ 를 형성함으 로써 장치의 성능과 안정성을 개선하기 위한 또 다른 연 구가 진행되었다.

기공 크기 및 터널 구조와 같은 물리적 특성이 다른 두가지 유형의 $\mathrm{Zr}-\mathrm{MOF}(\mathrm{MOF}-808$ 및 $\mathrm{UiO}-66)$ 를 중 간층과 하이브리드 $\mathrm{P}-\mathrm{MOF}$ 구조로 사용한 연구가 보고 되었다 ${ }^{183)}$. Fig. 13 (a) 및 (b)는 중간층 $\mathrm{MOF}$ 와 하이브 리드 $\mathrm{P}-\mathrm{MOF}$ 를 사용한 페로브스카이트 층의 $\mathrm{PL}$ 스펙 트럼을 보여준다. $\mathrm{MOF}$ 를 중간층으로 사용했을 때 페로 브스카이트와 $\mathrm{MOF}$ 사이의 계면에서 전하 이동이 촉진
되어 어느 정도의 PL quenching이 발생했다. 반면 하 이브리드 필름의 $\mathrm{PL}$ 강도는 기존 페로브스카이트 필름 에 비해 높았으며, 이러한 향상은 $\mathrm{P}-\mathrm{MOF}$ 에 의해 유 도된 결함 passivation을 의미한다. $\mathrm{Zr}-\mathrm{MOF}$ 를 중간 층 $\mathrm{MOF}$ 와 hybrid $\mathrm{P}-\mathrm{MOF}$ 구조로 사용했을 때 $\mathrm{PSCS}$ 의 $\mathrm{PCE}$ 는 $\mathrm{MOF}-808$ 보다 $\mathrm{UIO}-66$ 의 효율이 제어 장치 에 비해 더 향상된 것을 볼 수 있다(Fig. 13 (c) 및 (d)). $\mathrm{MOF}$ 와 페로브스카이트의 직접적인 혼성화는 페로브스 카이트 입자의 성장을 약간 억제하는 것으로 보이지만 전체적인 영향은 그다지 크지 않다(Fig. 13 (e)). 하이브 리드 $\mathrm{P}-\mathrm{MOF}$ 는 결함을 passivation을 허용하고 수분 침투에 대한 필름의 저항을 향상시켜 PSCs의 효율과 안 정성을 향상시킨다(Fig. $13(\mathrm{f}))$. 
일반적으로 $\mathrm{Zr}$ 기반의 $\mathrm{MOF}$ 는 고온에서 복잡한 합성 이 필요하므로 제조 공정에 약간의 어려움이 있다 ${ }^{184-188)}$. 대조적으로, 비교적 유연한 합성 조건과 적절한 안정성 을 갖는 In 기반의 MOF (In2)를 HTM으로 사용하여 밴 드 정렬을 통한 전하이동을 가속화시키고 $\mathrm{PSC}$ 의 광 응 답을 향상시킨 연구에 대해 앞서 설명했다 ${ }^{149)}$. In2는 마 찬가지로 하이브리드 $\mathrm{P}-\mathrm{MOF}$ 에 적용되었다 ${ }^{189)}$. 저자 는 $\mathrm{In} 2$ 를 $\mathrm{PbI}_{2}$ 전구체 용액과 혼합하여 $\mathrm{PSCs}$ 의 성능 을 향상시켰다. 대형 공액 In2 시스템은 전하 이동을 선 호하므로 $\mathrm{In} 2$ 는 $\mathrm{PbI}_{2}$ 전구체 용액에 잘 통합될 수 있 다. 연구에 따르면 부동태화 되지 않은 $\mathrm{Pb}^{2+}$ (메틸아민 의 손실로 인해)는 PSCs의 성능에 악영향을 미친다 ${ }^{190)}$. 따라서 $\mathrm{In} 2$ 의 첨가는 부분 $\mathrm{Pb}^{2+}$ 를 $\mathrm{Pb}^{0}$ 로 변경시켜 과 도한 $\mathrm{Pb}^{2+}$ 로 인한 성능 저하 문제를 해결하였다. In2 의 첨가량을 최적화한 결과, $\mathrm{PSCs}$ 의 $\mathrm{PCE}$ 는 $15.41 \%$
에서 $17.15 \%$ 로 크게 향상됐다. Zhou 등은 극도로 온 화한 조건하에서 microporous indium 기반의 $\mathrm{MOF}$ $\left[\mathrm{In}_{12} \mathrm{O}(\mathrm{OH})_{16}\left(\mathrm{H}_{2} \mathrm{O}\right)_{5}(\mathrm{btc})_{6}\right] \mathrm{n}$ ( $\left.\mathrm{In}-\mathrm{BTC}\right)$ 나노 결정을 합 성하고, 페로브스카이트와 혼합하여 PSCs를 제작했다 ${ }^{191)}$. In-BTC는 페로브스카이트의 형태와 결정성을 개선 하여 필름의 결정립계와 결함을 감소시키는 역할을 한 다. 따라서 In-BTC는 원시 PSCs (18.19\%)에 비해 향상 된 $\mathrm{PCE}$ (19.63\%)를 제공하며, 12 일 후에도 초기 $\mathrm{PCE}$ 의 $80 \%$ 이상이 유지되어 장기적인 안정성을 보여준다(원시 $\mathrm{PSCs}$ 는 12 일 후 초기 $\mathrm{PCE}$ 의 $35.4 \%$ 만 유지함).

$\mathrm{MOF}$ 기반 $\mathrm{PSCs}$ 를 요약하면, $\mathrm{MOF}$ 의 우수한 화학 적 및 열적 안정성 덕분에 $\mathrm{PSCs}$ 의 장기 안정성과 $\mathrm{PCE}$ 가 향상되었다(Table 2). MOF는 HTM, ETM, 중간층, 하이브리드 $\mathrm{P}-\mathrm{MOF}$ 와 같은 다양한 형태로 적용되었다. 적용된 형태와 $\mathrm{MOF}$ 물질은 다르지만 유사한 결과를 보

Table 2. Summary of the photovoltaic performance of MOF-derived PSCs discussed in the text.

\begin{tabular}{|c|c|c|c|c|c|c|}
\hline & MOF material & $\begin{array}{l}V_{o c} \\
(V)\end{array}$ & $\begin{array}{c}\mathrm{J}_{\mathrm{SC}} \\
\left(\mathrm{mA} / \mathrm{cm}^{2}\right)\end{array}$ & $\mathrm{FF}$ & $\begin{array}{l}\text { PCE } \\
(\%)\end{array}$ & ref \\
\hline \multirow{6}{*}{ ETM } & Co-doped Ti-MOF & 1.027 & 24.078 & 0.649 & 15.75 & 118 \\
\hline & $\mathrm{ZIF}-8$ & 0.936 & 21.6 & 0.62 & 12.4 & 119 \\
\hline & $\mathrm{ZIF}-8$ derived $\mathrm{ZnO}$ & 1.11 & 22.1 & 0.739 & 18.1 & 131 \\
\hline & ZIF-8 derived porous carbon & 1.06 & 22.13 & 0.72 & 17.32 & 132 \\
\hline & MIL-125(Ti)/PCBM & 1.082 & 23.18 & 0.755 & 18.94 & 136 \\
\hline & MIL-125(Ti) & 1.01 & 22.81 & 0.72 & 16.56 & 137 \\
\hline \multirow{6}{*}{ HTM } & $\operatorname{In} 2$ & 1.01 & 21.03 & 0.74 & 15.8 & 149 \\
\hline & In10 & 1.00 & 24.3 & 0.70 & 17.0 & 152 \\
\hline & POM@Cu-BTC & 1.11 & 23.90 & 0.80 & 21.44 & 153 \\
\hline & $\mathrm{CuO} @ \mathrm{NiO}$ & 0.91 & 21.80 & 0.51 & 10.11 & 157 \\
\hline & $2 \mathrm{D} \mathrm{Pb}-\mathrm{MOF}$ & 1.00 & 19.57 & 67.30 & 13.17 & 160 \\
\hline & 2D graphite NPC & 1.06 & 23.51 & 0.76 & 18.51 & 161 \\
\hline \multirow{5}{*}{ Interlayer } & $\mathrm{ZIF}-8$ & 1.02 & 22.82 & 0.73 & 16.99 & 173 \\
\hline & ZIF-8 (scaffold layer) & 1.23 & 21.8 & 0.59 & 16.8 & 175 \\
\hline & $\mathrm{NiO@C}$ & 1.018 & 22.394 & 0.69 & 15.78 & 176 \\
\hline & $\mathrm{MOF}-808$ & 1.068 & 19.64 & 0.79 & 16.55 & 183 \\
\hline & $\mathrm{UiO}-66$ & 1.067 & 20.25 & 0.78 & 17.01 & 183 \\
\hline \multirow{4}{*}{$\begin{array}{l}\text { Hybrid } \\
\text { Perovskite- } \\
\text { MOF }\end{array}$} & $\mathrm{MOF}-808$ & 1.062 & 21.01 & 0.80 & 17.81 & 183 \\
\hline & $\mathrm{UiO}-66$ & 1.072 & 21.85 & 0.77 & 18.01 & 183 \\
\hline & In2 & 1.04 & 23.18 & 0.71 & 17.15 & 189 \\
\hline & In-BTC & 1.10 & 22.99 & 0.77 & 19.63 & 191 \\
\hline
\end{tabular}


여주며 $\mathrm{PSCs}$ 에서 $\mathrm{MOF}$ 의 역할은 다음과 같이 정리할 수 있다 ${ }^{192,193)}$ : ( i ) 페로브스카이트 필름의 품질과 결정 도를 향상시킬 수 있다; (ii) 전하이동을 개선하고, 전하 재결합을 억제할 수 있다; (iii) 장치 안정성을 개선한다. 이러한 연구결과는 고효율 및 장기안정성을 갖춘 PSCs 의 향후 설계에 중요한 정보를 제공한다.

\section{4. 결론}

3 세대 태양전지의 상용화를 위해 해결해야 할 가장 큰 문제는 소자의 안정성이다. 특히, $\mathrm{PSCs}$ 는 단결정 실리 콘 태양전지와 유사한 높은 $\mathrm{PCE}$ 를 보임에도 불구하고 여전히 장기적인 안정성 성능이 부족하다. 따라서 $\mathrm{PSCS}$ 의 성능과 안정성을 향상시키는 데 초점을 맞춘 연구가 계속되고 있다. $\mathrm{MOF}$ 는 고유한 특성으로 광범위한 응용 분야에 사용되고 있다. 특히, 구성 성분을 변경하여 밴 드 갭을 쉽게 조정할 수 있는 장점은 $\mathrm{MOF}$ 를 $\mathrm{PSCS}$ 에 적 용하기에 매력적인 재료로 만든다. 본 리뷰에서는 PSCs 의 성능과 안정성 향상을 위해 $\mathrm{MOF}$ 재료를 사용한 연 구를 소개하였다. $\mathrm{MOF}$ 와 $\mathrm{MOF}$ 유래 물질은 $\mathrm{PSCs}$ 의 다 양한 위치에 배치되어 페로브스카이트 필름의 품질을 개선하고 전하전달을 향상시키며 전하 재결합을 억제할 수 있다. 따라서 $\mathrm{MOF}$ 와 $\mathrm{MOF}$ 유래 물질은 $\mathrm{PSCs}$ 의 효 율 향상과 안정성 향상에 크게 기여한다. 하지만 아직 정확한 mechanism이 밝혀지지 않았기에, 다양한 정밀 분석 기법을 활용하여 최적의 $\mathrm{MOF}$ 를 찾기 위한 통찰력 있는 연구가 필요하다. $\mathrm{MOF}$ 는 $\mathrm{MOF}$ 유래 물질로 확장 되어 사용할 수 있으므로, 가까운 시일내에 PSCs의 효 율 향상과 고안정성 확보에서 큰 역할을 할 것으로 예상 된다.

\section{사사}

본 연구는 한국연구재단 지원사업에 의하여 수행되었 음 (2018R1A4A1022647; 2020R1A2C2100670).

\section{REFERENCES}

1. Y.H. Hu, and L. Zhang, "Hydrogen storage in metalorganic frameworks," Adv. Mater, 22, E117-E130 (2010).

2. N.L. Rosi, J. Eckert, M. Eddaoudi, D.T. Vodak, J. Kim, M. O'Keeffe, O.M. Yaghi, "Hydrogen storage in microporous metal-organic frameworks," Science, $\mathbf{3 0 0}$, 1127-1129 (2003).

3. Y. Lin, C. Kong, Q. Zhang, L. Chen, "Metal-organic frameworks for carbon dioxide capture and methane storage," Adv. Energy Mater, 7, 1601296 (2017).

4. H. Li, K. Wang, Y. Sun, C.T. Lollar, J. Li, H.-C. Zhou, "Recent advances in gas storage and separation using metal-organic frameworks," Mater. Today, 21, 108121 (2018).

5. J.B. DeCoste, and G.W. Peterson, "Metal-organic frameworks for air purification of toxic chemicals," Chem. Rev., 114, 5695-5727 (2014).

6. C.G. Silva, A. Corma, H. García, "Metal-organic frameworks as semiconductors," J. Mater. Chem., 20, 3141-3156 (2010).

7. C.C. Wang, J.R. Li, X.L. Lv, Y.Q. Zhang, G. Guo, "Photocatalytic organic pollutants degradation in metal-organic frameworks," Energy Environ. Sci., 7, 2831-2867 (2014).

8. E.M. Dias, and C. Petit, "Towards the use of metalorganic frameworks for water reuse: a review of the recent advances in the field of organic pollutants removal and degradation and the next steps in the field," J. Mater. Chem. A, 3, 22484-22506 (2015).

9. C.-Y. Sun, C. Qin, X.-L. Wang, Z.-M. Su, "Metalorganic frameworks as potential drug delivery systems," Expert Opin. Drug Deliv., 10, 89-101 (2013).

10. I.A. Lázaro, and R.S. Forgan, "Application of zirconium MOFs in drug delivery and biomedicine," Coord. Chem. Rev., 380, 230-259 (2019).

11. B.F. Hoskins, and R.J. Robson, "Infinite polymeric frameworks consisting of three dimensionally linked rod-like segments," Am. Chem. Soc., 111, 5962-5964 (1989).

12. B.F. Hoskins, and R.J. Robson, "Design and construction of a new class of scaffolding-like materials comprising infinite polymeric frameworks 
of 3D-linked molecular rods. A reappraisal of the zinc cyanide and cadmium cyanide structures and the synthesis and structure of the diamondrelated frameworks $\left[\mathrm{N}\left(\mathrm{CH}_{3}\right)_{4}\right]\left[\mathrm{Cu}^{\mathrm{I}} \mathrm{Zn}^{\mathrm{II}}(\mathrm{CN})_{4}\right]$ and $\mathrm{Cu}^{\mathrm{I}}\left[4,4^{\prime}, 4\right.$ ", 4 “" -tetracyanotetraphenylmethane $]$ $\mathrm{BF}_{4} \cdot \mathrm{xC}_{6} \mathrm{H}_{5} \mathrm{NO}_{2}$," J. Am. Chem. Soc., 112, 1546-1554 (1990).

13. O.M. Yaghi, G.M. Li, H.L. Li, "Selective binding and removal of guests in microporous metal-organic framework," Nature, 378, 703-706 (1995).

14. M. Kondo, T. Yoshitomi, K. Seki, H. Matsuzaka, S. Kitagawa, "Three-dimensional framework with channeling cavities for small molecules: $\left\{\left[\mathrm{M}_{2}\left(4,4^{\prime}-\right.\right.\right.$ bpy $\left.\left.)_{3}\left(\mathrm{NO}_{3}\right)_{4}\right] \cdot \mathrm{xH}_{2} \mathrm{O}\right\}_{\mathrm{n}}(\mathrm{M}=\mathrm{Co}, \mathrm{Ni}, \mathrm{Zn})$, , Angew. Chem., Int. Ed., 36, 1725-1727 (1997).

15. C. Livage, C. Egger, G. Ferey, "Hybrid open networks (MIL 16): synthesis, crystal structure, and ferrimagnetism of $\mathrm{Co}_{4}(\mathrm{OH})_{2}\left(\mathrm{H}_{2} \mathrm{O}\right)_{2}\left(\mathrm{C}_{4} \mathrm{H}_{4} \mathrm{O}_{4}\right)_{3} \cdot 2 \mathrm{H}_{2} \mathrm{O}$, a new layered cobalt(II) carboxylate with 14-membered ring channels," Chem. Mater., 11, 1546-1550 (1999).

16. M. Hu, J. Reboul, S. Furukawa, N.L. Torad, Q.M. Ji, P. Srinivasu, K. Ariga, S. Kitagawa, Y. Yamauchi, "Direct carbonization of Al-based porous coordination polymer for synthesis of nanoporous carbon," J. Am. Chem. Soc., 134, 2864-2867 (2012).

17. H. Konnerth, B.M. Matsagar, S.S. Chen, M.H.G. Prechtl, F.-K. Shieh, K.C.-W. Wu, "Metal-organic framework (MOF)-derived catalysts for fine chemical production," Coord. Chem. Rev., 416, 213319 (2020).

18. B. Singh, and A. Indra, "Designing self-supported metal-organic framework derived catalysts for electrochemical water splitting," Chem Asian J., 15, 607-623 (2020).

19. P. Pachfule, R. Das, P. Poddar, R. Banerjee, "Solvothermal synthesis, structure, and properties of metal organic framework isomers derived from a partially fluorinated link," Cryst. Growth Des., 11, 1215-1222 (2011).

20. Y. Ban, Y. Li, X. Liu, Y. Peng, W. Yang, “Solvothermal synthesis of mixed-ligand metal-organic framework ZIF-78 with controllable size and morphology," Microporous Mesoporous Mat., 173, 29-36 (2013).

21. X. Wang, N. Yang, Q. Li, F. He, Y. Yang, B. Wu, J. Chu, A. Zhou, S. Xiong, "Solvothermal synthesis of flower-string-like NiCo-MOF/MWCNT composites as a high-performance supercapacitor electrode material," J. Solid State Chem., 277, 575-586 (2019).

22. Z. Ni, and R.I. Masel, "Rapid production of metalorganic frameworks via microwave-assisted solvothermal synthesis," J. Am. Chem. Soc., 128, 38 (2006).

23. R. Vakili, S. Xu, N. Al-Janabi, P. Gorgojo, S.M. Holmes, X. Fan, "Microwave-assisted synthesis of zirconium-based metal organic frameworks (MOFs): optimization and gas adsorption," Microporous Mesoporous Mat., 260, 45-53 (2018).

24. J. Cui, N. Gao, C. Wang, W. Zhu, J. Li, H. Wang, P. Seidel, B.J. Ravoo, G. Li, "Photonic metal-organic framework composite spheres: a new kind of optical material with self-reporting molecular recognition," Nanoscale, 6, 11995 (2014).

25. D. Lv, Y. Chen, Y. Li, R. Shi, H. Wu, X. Sun, J. Xiao, H. Xi, Q. Xia, Z. Li, "Efficient mechanochemical synthesis of MOF-5 for linear alkanes adsorption," $J$. Chem. Eng. Data, 62, 2030-2036 (2017).

26. Y. Chen, H. Wu, Z. Liu, X. Sun, Q. Xia, Z. Li, "Liquid-assisted mechanochemical synthesis of copper based MOF-505 for the separation of $\mathrm{CO}_{2}$ over $\mathrm{CH}_{4}$ or $\mathrm{N}_{2}$," Ind. Eng. Chem. Res., 57, 703-709 (2018).

27. W.-J. Son, J. Kim, J. Kim, W.-S. Ahn, "Sonochemical synthesis of MOF-5," Chem. Commun., 47, 63366338 (2008).

28. D.-A. Yang, H.-Y. Cho, J. Kim, S.-T. Yang, W.-S. Ahn, " $\mathrm{CO}_{2}$ capture and conversion using Mg-MOF-74 prepared by a sonochemical method," Energy Environ. Sci., 5, 6465 (2012).

29. N. Campagnol, T.V. Assche, T. Boudewijns, J. Denayer, K. Binnemans, D.D. Vos, J. Fransaer, "High pressure, high temperature electrochemical synthesis of metal-organic frameworks: films of MIL-100 (Fe) and HKUST-1 in different morphologies," J. Mater. Chem. A, 1, 5827 (2013).

30. H.M. Yang, X.L. Song, T.L. Yang, Z.H. Liang, C.M Fan, X.G. Hao, "Electrochemical synthesis of flower shaped morphology MOFs in an ionic liquid system and their electrocatalytic application to the hydrogen evolution reaction," $R S C A d v$., 4, 15720 (2014).

31. V.R. Remya, and M. Kurian, "Synthesis and catalytic applications of metal-organic frameworks: a review on recent literature," Int. Nano Lett., 9, 17-29 (2019). 
32. R. Long, J. Liu, O.V. Prezhdo, "Unravelling the effects of grain boundary and chemical doping on electron-hole recombination in $\mathrm{CH}_{3} \mathrm{NH}_{3} \mathrm{PbI}_{3}$ perovskite by time-domain atomistic simulation," $J$. Am. Chem. Soc., 138, 3884-3890 (2016).

33. P. Zhu, S. Hu, X. Luo, Y. Gao, S. Li, J. Zhu, H. Tan, "Simultaneous contact and grain-boundary passivation in planar perovskite solar cells using $\mathrm{SnO}_{2}-\mathrm{KCl}$ composite electron transport layer," $A d v$. Energy Mater, 10, 1903083 (2020).

34. W. Chen, Y. Wang, G. Pang, C.W. Koh, A.B. Djurišic, Y. Wu, B. Tu, F.-z. Liu, R. Chen, H.Y. Woo, X. Guo, Z. He, "Conjugated polymer-assisted grain boundary passivation for efficient inverted planar perovskite solar cells," Adv. Funct. Mater, 29, 1808855 (2019).

35. C. Ulbrich, A. Gerber, K. Hermans, A. Lambertz, U. Rau, "Analysis of short circuit current gains by an anti-reflective textured cover on silicon thin film solar cells," Prog. Photovolt: Res. Appl., 21, 1672-1681 (2013).

36. D. Bouhafs, A. Moussi, A. Chikouche, J.M. Ruiz, "Design and simulation of antireflection coating systems for optoelectronic devices: application to silicon solar cells," Sol. Energy Mater. Sol. Cells, 52, 79-93 (1998).

37. T. Fellmeth, A. Born, A. Kimmerle, F. Clement, D. Biro, R. Preu, "Recombination at metal-emitter interfaces of front contact technologies for highly efficient silicon solar cells," Energy Procedia, 8, $115-121$ (2018).

38. H.Q. Pham, T. Mai, N.N. Pham-Tran, Y. Kawazoe, H. Mizuseki, D. Nguyen-Manh, "Engineering of band gap in metal-organic frameworks by functionalizing organic linker: a systematic density functional theory investigation," J. Phys. Chem. C, 118, 4567-4577 (2014).

39. Z. Guo, D.K. Panda, M.A. Gordillo, A. Khatun, H. Wu, W. Zhou, S. Saha, "Lowering band gap of an electroactive metal-organic framework via complementary guest intercalation," ACS Appl. Mater. Interfaces, 9, 32413-32417 (2017).

40. A. Aziz, A.R. Ruiz-Salvador, N.C. Hernández, S. Calero, S. Hamad, R. Grau-Crespo, "Porphyrinbased metal-organic frameworks for solar fuel synthesis photocatalysis: band gap tuning via iron substitutions," J. Mater. Chem. A, 5, 11894-11904
(2017).

41. L.-M. Yang, G.-Y. Fang, J. Ma, R. Pushpa, E. Ganz, "Halogenated MOF-5 variants show new configuration, tunable band gaps and enhanced optical response in the visible and near infrared," Phys. Chem. Chem. Phys., 18, 32319-32330 (2016).

42. R. Tang, S. Zhou, L. Zhang, L. Yin, "Metal-organic framework derived narrow bandgap cobalt carbide sensitized titanium dioxide nanocage for superior photo-electrochemical water oxidation performance," Adv. Funct. Mater, 28, 1706154 (2018).

43. C.-K. Lin, D. Zhao, W.-Y. Gao, Z. Yang, J. Ye, T. Xu, Q. Ge, S. Ma, D.-J. Liu, "Tunability of band gaps in metal-organic frameworks," Inorg. Chem., 51, 9039 9044 (2012).

44. S. Sharma, K.K. Jain, A. Sharma, "Solar cells: in research and applications-a review," Mater. Sci. Appl., 6, 62181 (2015).

45. C.P. Muzzillo, "Review of grain interior, grain boundary, and interface effects of K in CIGS solar cells: mechanisms for performance enhancement," Sol. Energy Mater. Sol. Cells, 172, 18-24 (2017).

46. S. Zhang, J. Zhang, M. Abdelsamie, Q. Shi, Y. Zhang, T.C. Parker, E.V. Jucov, T.V. Timofeeva, A. Amassian, G.C. Bazan, S.B. Blakey, S. Barlow, S.R. Marder, "Intermediate-sized conjugated donor molecules for organic solar cells: comparison of benzodithiophene and benzobisthiazole-based cores," Chem. Mater., 29, 7880-7887 (2017).

47. Y. Fan, K. Ziabrev, S. Zhang, B. Lin, S. Barlow, S.R. Marder, "Comparison of the optical and electrochemical properties of bi(perylene diimide)s linked through ortho and bay positions," ACS Omega, 2, 377-385 (2017).

48. Q. Fan, Y. Wang, M. Zhang, B. Wu, X. Guo, Y. Jiang, W. Li, B. Guo, C. Ye, W. Su, J. Fang, X. Ou, F. Liu, Z. Wei, T.C. Sum, T.P. Russell, Y. Li, "High-performance as-cast nonfullerene polymer solar cells with thicker active layer and large area exceeding $11 \%$ power conversion efficiency," Adv. Mater., 30, 1704546 (2018)

49. S. Li, L. Ye, W. Zhao, X. Liu, J. Zhu, H. Ade, J. Hou, "Design of a new small-molecule electron acceptor enables efficient polymer solar cells with high fill factor," Adv. Mater., 29, 1704051 (2017). 
50. S. Dai, F. Zhao, Q. Zhang, T.K. Lau, T. Li, K. Liu, Q. Ling, C. Wang, X. Lu, W. You, X. Zhan, "Fused nonacyclic electron acceptors for efficient polymer solar cells," J. Am. Chem. Soc., 139, 1336-1343 (2017).

51. H. Huang, L. Yang, A. Facchetti, T.J. Marks, "Organic and polymeric semiconductors enhanced by noncovalent conformational locks," Chem. Rev., 117, 10291-10318 (2017).

52. N.D. Eastham, J.L. Logsdon, E.F. Manley, T.J. Aldrich, M.J. Leonardi, G. Wang, N.E. Powers-Riggs, R.M. Young, L.X. Chen, M.R. Wasielewski, F.S. Melkonyan, R.P.H. Chang, T.J. Marks, "Hole-transfer dependence on blend morphology and energy level alignment in polymer: ITIC photovoltaic materials," Adv. Mater., 30, 1704263 (2018).

53. W. Ma, G. Yang, K. Jiang, J.H. Carpenter, Y. Wu, X. Meng, T. McAfee, J. Zhao, C. Zhu, C. Wang, H. Ade, H. Yan, "Influence of processing parameters and molecular weight on the morphology and properties of high-performance PffBT4T-2OD:PC71BM organic solar cells," Adv. Energy Mater., 5, 1501400 (2015).

54. G. Yu, J. Gao, J.C. Hummelen, F. Wudl, A.J. Heeger, "Polymer photovoltaic cells: enhanced efficiencies via a network of internal donor-acceptor heterojunctions," Science, 270, 1789-1791 (1995).

55. T. Dong, L. Lv, L. Feng, Y. Xia, W. Deng, P. Ye, B. Yang, S. Ding, A. Facchetti, H. Dong, H. Huang, "Noncovalent $\mathrm{Se} \cdots \mathrm{O}$ conformational locks for constructing high performing optoelectronic conjugated polymers," Adv. Mater., 29, 1606025 (2017).

56. S. Holliday, R.S. Ashraf, A. Wadsworth, D. Baran, S.A. Yousaf, C.B. Nielsen, C.H. Tan, S.D. Dimitrov, Z. Shang, N. Gasparini, M. Alamoudi, F. Laquai, C.J. Brabec, A. Salleo, J.R. Durrant, I. McCulloch, "High-efficiency and air-stable P3HT-based polymer solar cells with a new non-fullerene acceptor," Nat. Commun., 7, 11585 (2016).

57. C.Y. Lee, Q.V. Le, C. Kim, S.Y. Kim, "Use of silanefunctionalized graphene oxide in organic photovoltaic cells and organic light-emitting diodes," Phys. Chem. Chem. Phys., 14, 8541-9572 (2015).

58. T. P. Nguyen, Q.V. Le, K.S. Choi, J.H. Oh, Y.G. Kim, S.M. Lee, S.T. Chang, Y.-H. Cho, S. Choi, T.-Y. Kim, S.Y. Kim, " $\mathrm{MoS}_{2}$ nanosheets exfoliated by sonication and their application to organic photovoltaic cells," Sci. Adv. Mater., 7, 700-705 (2015).

59. B. Adilbekova, Y. Lin, E. Yengel, H. Faber, G. Harrison, Y. Firdaus, A. El-Labban, D.H. Anjum, V. Tung, T.D. Anthopoulos, "Liquid phase exfoliation of $\mathrm{MoS}_{2}$ and $\mathrm{WS}_{2}$ in aqueous ammonia and their application in highly efficient organic solar cells," J. Mater. Chem. C, 8, 5259-5264 (2020).

60. W. Xing, P. Ye, J. Lu, X. Xu, Y. Chen, T. Zhu, A. Peng, H. Huang, "Tellurophene-based metal-organic framework nanosheets for high-performance organic solar cells,” J. Power Sources, 401, 13-19 (2018).

61. K. Sasitharan, D.G. Bossanyi, N. Vaenas, A.J. Parnell, J. Clark, A. Iraqi, D.G. Lidzey, J.A. Foster, "Metal-organic framework nanosheets for enhanced performance of organic photovoltaic cells," J. Mater. Chem. A, 8, 6067-6075 (2020).

62. I.A. Sahito, K.C. Sun, A.A. Arbab, M.B. Qadir, S.H. Jeong, "Graphene coated cotton fabric as textile structured counter electrode for DSSC," Electrochim. Acta, 173, 164-171 (2015).

63. H. Choi, H. Kim, S. Hwang, Y. Han, M. Jeon, "Graphene counter electrodes for dye-sensitized solar cells prepared by electrophoretic deposition," J. Mater. Chem., 21, 7548-7551 (2011).

64. B. O’Regan, and M. Grätzel, “A low-cost, highefficiency solar cell based on dye-sensitized colloidal $\mathrm{TiO}_{2}$ films," Nature, 353, 737-740 (1991).

65. S. Mathew, A. Yella, P. Gao, R. Humphry-Baker, B.F. Curchod, N. Ashari-Astani, "Dye-sensitized solar cells with $13 \%$ efficiency achieved through the molecular engineering of porphyrin sensitizers," Nat. Chem., 6, 242-247 (2014).

66. K. Ogiya, C. Lv, A. Suzuki, R. Sahnoun, M. Koyama, H. Tsuboi, "Simulation of electron diffusion in $\mathrm{TiO}_{2}$ porous structures in dye-sensitized solar cells," Jpn. J. Appl. Phys., 48, 04C166 (2009).

67. Y. Wang, D. Wu, L.M. Fu, X.C. Ai, D. Xu, J.P. Zhang, "Correlation between energy and spatial distribution of intragap trap states in the $\mathrm{TiO}_{2}$ photoanode of dyesensitized solar cells," ChemPhysChem, 16, 2253 2259 (2015).

68. N.A. Karim, U. Mehmood, H.F. Zahid, T. Asif, "Nanostructured photoanode and counter electrode materials for efficient dye-sensitized solar cells 
(DSSCs)," Sol. Energy, 185, 165-188 (2019).

69. Z.L. Guo, J. Zhuang, Z. Ma, H.R. Xia, X. Wen, "Enhanced electron extraction using $\mathrm{ZnO} / \mathrm{ZnO}-\mathrm{SnO}_{2}$ solid double-layer photoanode thin films for efficient dye sensitized solar cells," Thin Solid Films, 684, 1-8 (2019).

70. K. Koh, A.G. Wong-Foy, A.J. Matzger, “A crystalline mesoporous coordination copolymer with high microporosity," Angew. Chem., Int. Ed., 47, 677-680 (2008).

71. Y. Li, A. Pang, C. Wang, M. Wei, "Metal-organic frameworks: promising materials for improving the open circuit voltage of dye-sensitized solar cells," $J$. Mater. Chem., 21, 17259 (2011).

72. R. Tang, Z. Xie, S. Zhou, Y. Zhang, Z. Yuan, L. Yin, " $\mathrm{Cu}_{2} \mathrm{ZnSnS}_{4}$ nanoparticle sensitized metal-organic framework derived mesoporous $\mathrm{TiO}_{2}$ as photoanodes for high-performance dye-sensitized solar cells," ACS Appl. Mater. Interfaces, 8, 22201-22212 (2016).

73. M. Wu, X. Lin, T. Wang, J. Qiu, T. Ma, "Low-cost dye-sensitized solar cell based on nine kinds of carbon counter electrodes," Energy Environ. Sci., 4, 2308-2315 (2011).

74. G. Zhu, L. Pan, T. Lu, T. Xu, Z. Sun, "Electrophoretic deposition of reduced graphene-carbon nanotubes composite films as counter electrodes of dyesensitized solar cells," J. Mater. Chem., 21, 14869-14875 (2011).

75. F. Gong, H. Wang, X. Xu, G. Zhou, Z.S. Wang, "In situ growth of $\mathrm{Co}_{(0.85)} \mathrm{Se}$ and $\mathrm{Ni}_{(0.85)}$ Se on conductive substrates as high-performance counter electrodes for dye-sensitized solar cells," J. Am. Chem. Soc., 134, 10953-10958 (2012).

76. G.R. Li, J. Song, G.L. Pan, X.P. Gao, "Highly Pt-like electrocatalytic activity of transition metal nitrides for dye-sensitized solar cells," Energy Environ. Sci., 4, 1680-1683 (2011).

77. X. Sun, J. Dou, F. Xie, Y. Li, M. Wei, “One-step preparation of mirror-like NiS nanosheets on ITO for the efficient counter electrode of dye-sensitized solar cells," Chem. Commun., 50, 9869-9871 (2014).

78. S. Peng, J. Shi, J. Pei, Y. Liang, F. Cheng, J. Liang, J. Chen, "Ni $i_{1-X} \mathrm{Pt}_{\mathrm{X}}(\mathrm{X}=0-0.08)$ films as the photocathode of dye-sensitized solar cells with high efficiency," Nano Res., 2, 484-492 (2009).
79. R. Trevisan, M. Dobbelin, P.P Boix, E.M. Barea, R. Tena-Zaera, I. Mora-Sero, J. Bisquert, "PEDOT nanotube arrays as high performing counter electrodes for dye sensitized solar cells. Study of the interactions among electrolytes and counter electrodes," $A d v$. Energy Mater., 1, 781-784 (2011).

80. J. Ou, J. Xiang, J. Liu, L. Sun, "Surface-supported metal-organic framework thin-film-derived transparent $\mathrm{CoS}_{1.097} @ \mathrm{~N}$-doped carbon film as an efficient counter electrode for bifacial dye-sensitized solar cells," ACS Appl. Mater. Interfaces, 11, 14862 14870 (2019).

81. F. Bella, R. Bongiovanni, R.S. Kumar, M.A Kulandainathan, A.M. Stephan, "Light cured networks containing metal organic frameworks as efficient and durable polymer electrolytes for dye-sensitized solar cells," J. Mater. Chem. A, 1, 9033 (2013).

82. E.D. Spoerke, L.J. Small, M.E. Foster, J. Wheeler, A.M. Ullman, V. Stavila, M. Rodriguez, M.D. Allendorf, "MOF-sensitized solar cells enabled by a pillared porphyrin framework," J. Phys. Chem. C, 121, 4816-4824 (2017)

83. A.V. Vinogradov, H. Zaake-Hertling, E. HeyHawkins, A.V. Agafonov, G.A. Seisenbaeva, V.G. Kessler, V.V. Vinogradov, "The first depleted heterojunction $\mathrm{TiO}_{2}-\mathrm{MOF}-$ based solar cell," Chem. Commun., 50, 10210-10213 (2014).

84. S. Alwin, V. Ramasubbu, X.S. Shajan, " $\mathrm{TiO}_{2}$ aerogelmetal organic framework nanocomposite: a new class of photoanode material for dye-sensitized solar cell applications," Bull. Mater. Sci., 41, 27 (2018).

85. P. Ranganathan, R. Sasikumar, S.-M. Chen, S.-P. Rwei, P. Sireesha, "Enhanced photovoltaic performance of dye-sensitized solar cells based on nickel oxide supported on nitrogen-doped graphene nanocomposite as a photoanode," $\circlearrowright$. Colloid Interface Sci., 504, 570-578 (2017).

86. S.V. Ingale, P.U. Sastry, P.B. Wagh, A.K. Tripathi, R. Rao, R. Tewari, P.T. Rao, R.P. Patel, A.K. Tyagi, S.C. Gupta, "Synthesis and micro structural investigations of titania-silica nano composite aerogels," Mater. Chem. Phys., 135, 497-502 (2012).

87. V. Ramasubbu, P.R. Kumar, E.M. Mothi, K. Karuppasamy, H.-S. Kim, T. Maiyalagan, X.S. Shajan, "Highly interconnected porous $\mathrm{TiO}_{2}-\mathrm{Ni}$ MOF composite aerogel photoanodes for high power 
conversion efficiency in quasi-dye sensitized solar cells," Appl. Surf. Sci., 496, 143646 (2019).

88. S. Liu, Z. Li, K. Zhao, M. Hao, Z Zhang, L. Li, Y. Zhang, W. Zhang, "A facile hydrothemal synthesis of $\mathrm{MoS}_{2} @ \mathrm{Co}_{3} \mathrm{~S}_{4}$ composites based on metal organic framework compounds as a high-efficiency liquidstate solar cell counter electrode," J. Alloys Compd., 831, 154910 (2020).

89. J. Yang, Y. Niu, J. Huang, L. Liu, X. Qian, "N-doped $\mathrm{C} / \mathrm{CoSe}_{2} @ \mathrm{Co}-\mathrm{FeSe}_{2}$ yolk-shell nano polyhedron as superior counter electrode catalyst for high-efficiency Pt-free dye-sensitized solar cell," Electrochim. Acta, 330, 135333 (2020).

90. Z. Xie, X. Cui, W. Xu, Y. Wang, "Metal-organic framework Derived CoNi@CNTs embedded carbon nanocages for efficient dye-sensitized solar cells," Electrochim. Acta, 229, 361-370 (2017).

91. J. Ou, C. Gong, M. Wang, J. Xiang, J. Liu, "Highly efficient ZIF-8/graphene oxide derived N-doped carbon sheets as counter electrode for dye-sensitized solar cells," Elctrochim. Acta, 286, 212-218 (2018).

92. I.J. Kramer, J.C. Minor, G. Moreno-Bautista, L. Rollny, P. Kanjanaboos, D. Kopilovic, S.M. Thon, G.H. Carey, K.W. Chou, D. Zhitomirsky, A. Amassian, E.H. Sargent, "Efficient spray-coated colloidal quantum dot solar cells," Adv. Mater., 27, 116 (2015).

93. M.R. Kim, and D. Ma, "Quantum-dot-based solar cells: recent advances, strategies, and challenges," $J$. Phys. Chem. Lett., 6, 85 (2015).

94. R. Wang, Y. Shang, P. Kanjanaboos, W. Zhou, Z. Ning, E.H. Sargent, "Colloidal quantum dot ligand engineering for high performance solar cells," Energy Environ. Sci., 9, 1130-1143 (2016).

95. Z. Zheng, H. Ji, P. Yu, Z. Wang, "Recent progress towards quantum dot solar cells with enhanced optical absorption," Nanoscale Res. Lett., 11, 266 (2016).

96. K.A. Sablon, J.W. Little, V. Mitin, A. Sergeev, N. Vagidov, K. Reinhardt, "Strong enhancement of solar cell efficiency due to quantum dots with built-in charge," Nano Lett., 11, 2311-2317 (2011).

97. R. Kaur, A.L. Sharma, K.-H. Kim, A. Deep, “A novel $\mathrm{CdTe} / \mathrm{Eu}-\mathrm{MOF}$ photoanode for application in quantum dot-sensitized solar cell to improve power conversion efficiency," J. Ind. Eng. Chem., 53, 77-81
(2017).

98. W. Xu, Y. Sun, B. Ding, J. Zhang, "Zeoliteimidazolate frameworks derived Pt-free counter electrodes for high-performance quantum dotsensitized solar cells," R. Soc. Open Sci., 5, 180335 (2018).

99. A. Kojima, K. Teshima, Y. Shirai, T. Miyasaka, "Organometal halide perovskites as visible-light sensitizers for photovoltaic cells," J. Am. Chem. Soc., 131, 6050-6051 (2009).

100. NREL Best Research-Cell Efficiencies. Available online: https://www.nrel.gov/pv/assets/pdfs/bestresearch-cell-efficiencies.20200311.pdf (accessed on 11 March 2020).

101. Z. Song, S.C. Watthage, A.B. Phillips, M.J. Heben, "Pathways toward high-performance perovskite solar cells: review of recent advances in organo-metal halide perovskites for photovoltaic applications," $J$. Photonics Energy, 6, 022001 (2016).

102. M.S.G. Gamed, and G.T. Molar, "Mixed halide perovskite solar cells: progress and challenges," Crit. Rev. Solid State Mat. Sci., 45, 85-112 (2020).

103. Z. Zhu, D. Zhao, C.-C. Chueh, X. Shi, Z. Li, A.K.-Y. Jen, "Highly efficient and stable perovskite solar cells enabled by all-crosslinked charge-transporting layers," Joule, 2, 168-183 (2018).

104. C.-H. Tsai, N. Li, C.-C. Lee, H.-C. Wu, Z. Zhu, L. Wang, W.-C. Chen, H. Yan, C.-C. Chueh, "Efficient and UV-stable perovskite solar cells enabled by side chain-engineered polymeric hole-transporting layers," J. Mater. Chem. A, 6, 12999-13004 (2018).

105. G.E. Eperon, G.M. Patern, R.J. Sutton, A. Zampetti, A.A. Haghighirad, F. Cacialli, H.J. Snaith, "Inorganic caesium lead iodide perovskite solar cells," J. Mater. Chem. A, 3, 19688-19695 (2015).

106. D.Y. Heo, S.M. Han, N.S. Woo, Y.J. Kim, T.-Y. Kim, Z. Luo, S.Y. Kim, "Role of additives on the performance of $\mathrm{CsPbI}_{3}$ solar cells," J. Pys. Chem. C, 122, 15903-15910 (2018).

107. Q. Ma, S. Huang, X. Wen, M.A. Green, A.W.Y.H. Baillie, "Hole transport layer free inorganic $\mathrm{CsPbIr}_{2}$ perovskite solar cell by dual source thermal evaporation," Adv. Energy Mater., 6, 1502202 (2016).

108. D.Y. Heo, T.H. Lee, A. Iwan, L. Kavan, M. 
Omatova, E. Majkova, K. Kamaras, H.W. Jang, S.Y. Kim, "Effect of lead thiocyanate ions on performance of tin-based perovskite solar cells," $J$. Power Sources, 458, 228067 (2020).

109. M. Saliba, T. Matsui, K. Domanski, J.-Y. Seo, A. Ummadisingu, S.M. Zakeeruddin, J.-P.C.W. Baena, R. Tress, A. Abate, A. Hagfeldt, M. Grätzel, "Incorporation of rubidium cations into perovskite solar cells improves photovoltaic performance," Science, 354, 206-209 (2016).

110. D.Y. Heo, Z. Luo, S.Y. Kim, “Effect of ammonium halide additives on the performance of methyl amine based perovskite solar cells," Materials, 11, 1417 (2018).

111. F. Sadegh, S. Akin, M. Moghadam, V. Mirkhani, M.A. R.-Preciado, Z. Wang, M.M. Tavakoli, M. Graetzel, A. Hagfeldt, W. Tress, "Highly efficient, stable and hysteresis-less planar perovskite solar cell based on chemical bath treated $\mathrm{Zn}_{2} \mathrm{SnO}_{4}$ electron transport layer," Nano Energy, 75, 105038 (2020).

112. J. Jia, J. Dong, J. Wu, H. Wei, B. Cao, “Combustion procedure deposited $\mathrm{SnO}_{2}$ electron transport layers for high efficient perovskite solar cells," J. Alloys Compd., 844, 156032 (2020).

113. S. Javaid, C.W. Myung, S. Pourasad, B. Rakshit, K.S. Kim, G. Lee, "A highly hydrophobic fluorographene-based system as an interlayer for electron transport in organic-inorganic perovskite solar cells," J. Mater. Chem. A, 6, 18635-18640 (2018).

114. C. Liu, W. Li, J. Chen, J. Fan, Y. Mai, R.E.I. Schropp, "Ultra-thin $\mathrm{MoO}_{\mathrm{x}}$ as cathode buffer layer for the improvement of all-inorganic $\mathrm{CsPbIBr}_{2}$ perovskite solar cells," Nano Energy, 41, 75-83 (2017).

115. X. Chen, S. S. Mao, "Titanium dioxide nanomaterials: synthesis, properties, modifications, and applications," Chem. Rev., 107, 2891-2959 (2007).

116. Y. Bai, I. Mora-Sero, F. de Angelis, J. Bisquert, P. Wang, "Titanium dioxide nanomaterials for photovoltaic applications," Chem. Rev., 114, 10095-10130 (2014).

117. D. Wei, J. Ji, D. Song, M. Li, P. Cui, Y. Li, J. M. Mbengue, W. Zhou, Z. Ning, N.-G. Park, "A $\mathrm{TiO}_{2}$ embedded structure for perovskite solar cells with anomalous grain growth and effective electron extraction," J. Mater. Chem. A, 5, 1406-1414 (2017).

118. T.M.H. Nguyen, and C.W. Bark, "Synthesis of cobalt-doped $\mathrm{TiO}_{2}$ based on metal-organic frameworks as an effective electron transport material in perovskite solar cells," ACS Omega, 5, 2280-2286 (2020).

119. H.-Y. Chung, C.-H. Lin, S. Prabu, H.-W. Wang, "Perovskite solar cells using $\mathrm{TiO}_{2}$ layers coated with metal-organic framework material ZIF-8," J. Chin. Chem. Soc., 65, 1476-1481 (2018).

120. Z.-L. Tseng, C.-H. Chiang, C.-G. Wu, "Surface engineering of $\mathrm{ZnO}$ thin film for high efficiency planar perovskite solar cells," Sci. Rep., 5, 13211 (2015).

121. P. Zhang, J. Wu, T. Zhang, Y. Wang, D. Liu, H. Chen, C. Ji, C. Liu, W. Ahmad, Z.D. Chen, S. $\mathrm{Li}$, "Perovskite solar cells with $\mathrm{ZnO}$ electrontransporting materials," Adv. Mater., 30, 1703737 (2018).

122. J. Duan, Q. Xiong, B. Feng, Y. Xu, J. Zhang, H. Wang, "Low-temperature processed $\mathrm{SnO}_{2}$ compact layer for efficient mesostructured perovskite solar cells,” Appl. Surf. Sci., 391, 677-683 (2017).

123. A.J. Yun, J. Kim, T. Hwang, B. Park, “Origins of efficient perovskite solar cells with low-temperature processed $\mathrm{SnO}_{2}$ electron transport layer," ACS Appl. Energy Mater., 2, 3554-3560 (2019).

124. K. Mahmood, B.S. Swain, A. Amassian, "Doublelayered $\mathrm{ZnO}$ nanostructures for efficient perovskite solar cells," Nanoscale, 6, 14674-14678 (2014).

125. Z.L. Wang, "Zinc oxide nanostructures: growth, properties and applications," J. Phys.: Condens. Matter, 16, R829-R858 (2004).

126. G. Hu, W. Guo, R. Yu, X. Yang, R. Zhou, C. Ran, Z.L. Wang, "Enhanced performances of flexible $\mathrm{ZnO}$ /perovskite solar cells by piezo-phototronic effect," Nano Energy, 23, 27-33 (2016).

127. M.H. Kumar, N. Yantara, S. Dharani, M. Graetzel, S. Mhaisalkar, P.P. Boix, N. Mathews, "Flexible, low-temperature, solution processed $\mathrm{ZnO}$-based perovskite solid state solar cells," Chem. Commun., 49, 11089-11091 (2013).

128. P. Rong, S. Ren, Q. Yu, "Fabrications and applications of $\mathrm{ZnO}$ nanomaterials in flexible functional devices-review," Rev. Anal. Chem., 49, 
336-349 (2019).

129. J. Song, W. Hu, X.-F. Wang, G. Chen, W. Tian, T. Miyasaka, "HC( $\left(\mathrm{NH}_{2}\right)_{2} \mathrm{PbI}_{3}$ as a thermally stable absorber for efficient $\mathrm{ZnO}$-based perovskite solar cells," J. Mater. Chem., 4, 8435 (2016).

130. R.T. Ginting, E.-S. Jung, M.-K. Jeon, W.-Y. Jin, M. Song, J.-W. Kang, "Low-temperature operation of perovskite solar cells: with efficiency improvement and hysteresis-less," Nano Energy, 27, 569-576 (2016).

131. Y.-N. Zhang, B. Li, L. Fu, Q. Li, L.-W. Yin, "MOF-derived $\mathrm{ZnO}$ as electron transport layer for improving light harvesting and electron efficiency in perovskite solar cells," Electrochim. Acta, 330, 135280 (2019).

132. Z. Zhang, X. Luo, B. Wang, J. Zhang, "Electron transport improvement of perovskite solar cells via a ZIF-8 derived porous carbon skeleton," ACS Appl. Energy Mater., 2, 2760-2768 (2019).

133. H. F. Fu, Z. H. Wang, X. Wang, P. Wang, C. C. Wang, "Formation mechanism of rod-like ZIF-L and fast phase transformation from ZIF-L to ZIF-8 with morphology changes controlled by polyvinylpyrrolidone and ethanol," CrystEngComm, 20, 1473-1477 (2018).

134. M. Park, H. J. Kim, I. Jeong, J. Lee, H. Lee, H. J. Son, D.-E. Kim, M. J. Ko, "Flexible solar cells: mechanically recoverable and highly efficient perovskite solar cells: investigation of intrinsic flexibility of organic-inorganic perovskite," $A d v$. Energy Mater., 5, 1501406 (2015).

135. D. Yang, R. Yang, X. Ren, X. Zhu, Z. Yang, C. Li, S. Liu, "Hysteresis-suppressed high-efficiency flexible perovskite solar cells using solid-state ionic-liquids for effective electron transport," Adv. Mater., 28, 5206-5213 (2016).

136. U.J. Ryu, S. Jee, J.-S. Park, I.K. Han, J.H. Lee, M. Park, K.M. Choi, "Nanocrystalline titanium metalorganic frameworks for highly efficient and flexible perovskite solar cells," ACS Nano, 12, 4968-4975 (2018).

137. X. Hou, L. Pan, S. Huang, W.O. Yang, X. Chen, "Enhanced efficiency and stability of perovskite solar cells using porous hierarchical $\mathrm{TiO}_{2}$ nanostructures of scattered distribution as scaffold," Electrochim. Acta, 236, 351-358 (2017).
138. M.A. Mutalib, F. Aziz, A.F. Ismail, W.N. Salleh, N. Yusof, J. Jaafar, N.A. Ludin, "Towards high performance perovskite solar cells: a review of morphological control and HTM development," Appl. Mater. Today, 13, 69-82 (2018).

139. T.H. Schloemer, J.A. Christians, J.M. Luther, A. Sellinger, "Doping strategies for small molecule organic hole-transport materials: impacts on perovskite solar cell performance and stability," Chem. Sci., 10, 1904-1935 (2019).

140. H.S. Kim, C.R. Lee, J.H. Im, K.B. Lee, T. Moehl, A. Marchioro, S.-J. Moon, R. Humphry-Baker, J.-H. Yum, J.E. Moser, M. Grätzel, N.-G. Park, "Lead iodide perovskite sensitized all-solid-state submicron thin film mesoscopic solar cell with efficiency exceeding 9\%," Sci. Rep., 2, 591 (2012).

141. J.-Y. Seo, H.-S. Kim, S. Akin, M. Stojanovic, E. Simon, M. Fleischer, A. Hagfeldt, S.M. Zakeeruddin, M. Gratzel, "Novel p-dopant toward highly efficient and stable perovskite solar cells," Energy Environ. Sci., 11, 2985-2992 (2018).

142. Y. Hua, B. Xu, P. Liu, H. Chen, H. Tian, M. Cheng, L. Kloo, L. Sun, "High conductivity Ag-based metal organic complexes as dopant-free hole-transport materials for perovskite solar cells with high fill factors," Chem. Sci., 7, 2633-2638 (2016).

143. A. Abate, T. Leijtens, S. Pathak, J. Teuscher, R. Avolio, M.E. Errico, J. Kirkpatrik, J.M. Balls, P. Docampo, I. McPhersonc, H.J. Snaith, "Lithium salts as "redox active" p-type dopants for organic semiconductors and their impact in solid-state dyesensitized solar cells," Phys. Chem. Chem. Phys., 15, 2572-2579 (2013).

144. L. Huang, Z. Hu, J. Xu, K. Zhang, J. Zhang, J. Zhang, Y. Zhu, "Efficient and stable planar perovskite polar cells with a non-hygroscopic small molecule oxidant doped hole transport layer," Electrochim. Acta, 196, 328-336 (2016).

145. Z. Hawash, L.K. Ono, Y. Qi, "Recent advances in spiro-MeOTAD hole transport material and its applications in organic-inorganic halide perovskite solar cells," Adv. Mater. Interf., 5, 1700623 (2018).

146. X. Gu, Y. Li, Y. Mu, M. Zhang, T. Lu, P. Wang, " $\mathrm{FeCl}_{3}$ as a low-cost and efficient p-type dopant of spiro-OMeTAD for high performance perovskite solar cells," RSC Adv., 8, 9409-9413 (2018). 
147. E. Kasparavicius, A. Magomedov, T. Malinauskas, V. Getautis, "Long-term stability of the oxidized hole-transporting materials used in perovskite solar cells," Chem. Euro. J., 24, 9910-9918 (2018).

148. A. Pellaroque, N.K. Noel, S.N. Habisreutinger, Y. Zhang, S. Barlow, S.R. Marder, H.J. Snaith, "Efficient and stable perovskite solar cells using molybdenum tris (dithiolene) $\mathrm{s}$ as p-dopants for spiro-OMeTAD," ACS Energy Lett., 2, 2044-2050 (2017).

149. M. Li, D. Xia, Y. Yang, D. Xi, G. Dong, A. Jiang, R. Fan, "Doping of $\left.\left[\mathrm{In}_{2} \text { (phen) }\right)_{3} \mathrm{Cl}_{6}\right] \cdot \mathrm{CH}_{3} \mathrm{CN} \cdot 2 \mathrm{H}_{2} \mathrm{O}$ indium-based metal-organic framework into hole transport layer for enhancing perovskite solar cell efficiencies," Adv. Energy Mater., 8, 1702052 (2018).

150. K. Domanski, J.-P. Correa-Baena, N. Mine, M.K. Nazeeruddin, A. Abate, M. Saliba, W. Tress, A. Hagfeldt, M. Gratzel, "Not all that glitters is gold: metal-migration-induced degradation in perovskite solar cells," ACS Nano, 10, 6306 (2016).

151. K. Aitola, K. Domanski, J.-P. Correa-Baena, K. Sevinbjornsson, M. Saliba, A. Abate, M. Gratzel, E. Kauppinen, E.M.J. Jhoansson, W. Tress, A. Hagfeldt, G. Boschloo, "High temperature-stable perovskite solar cell based on low-cost carbon nanotube hole contact," Adv. Mater., 29, 1606398 (2017).

152. M. Li, J. Wang, A. Jiang, D. Xia, X. Du, Y. Dong, P. Wang, R. Fan, Y. Yang, "Metal organic framework doped spiro-OMeTAD with increased conductivity for improving perovskite solar cell performance," Solar Energy, 188, 380-385 (2019).

153. Y. Dong, J. Zhang, Y. Yang, L.L. Qiu, D. Xia, K. Lin, J. Wang, X. Fan, R. Fan, "Self-assembly of hybrid oxidantPOM@Cu-BTC for enhanced efficiency and long-term stability of perovskite solar cells," Angew. Chem., Int. Ed., 58, 17610-17615 (2019).

154. U. Er, K.C. Icli, M. Ozenbas, "Spin-coated copper (I) thiocyanate as a hole transport layer for perovskite solar cells," J. Solid State. Electrochem., 24, 293304 (2019).

155. X. Yin, Y. Guo, H. Xie, W. Que, L.B. Kong, "Nickel oxide as efficient hole transport materials for perovskite solar cells," Sol. RRL, 3, 1900001 (2019).

156. A. Corani, M.H. Li, P.S. Shen, P. Chen, T.F. Guo, A. Nahhas, K.B. Zheng, A. Yartsev, V. Sundstrom,
C.S. Ponseca, "Ultrafast dynamics of hole injection and recombination in organometal halide perovskite using nickel oxide as p-type contact electrode," $J$. Phys. Chem. Lett., 7, 1096-1101 (2016).

157. F. Hazeghi, S. Mozaffari, S.M.B. Ghorashi, "Metal organic framework-derived core-shell CuO@NiO nanosphares as hole transport material in perovskite solar cell," J. Solid State Electrochem., 24, $1427-$ 1438 (2020).

158. K.S. Burch, D. Mandrus, J.G. Park, "Magnetism in two-dimensional van der waals materials," Nature, 563, 47-52 (2018).

159. Z. Jin, J. Yan, X. Huang, W. Xu, S. Yang, D. Zhu, J. Wang, "Solution-processed transparent coordination polymer electrode for photovoltaic solar cells," Nano Energy, 40, 376-381 (2017).

160. L. Huang, X. Zhou, R. Wu, C. Shi, R. Xue, J. Zou, C. Xu, J. Zhao, W. Zeng, "Oriented haloing metalorganic framework providing high efficiency and high moisture-resistance for perovskite solar cells," J. Power Sources, 433, 226699 (2019).

161. X. Zhou, L. Qiu, R. Fan, A. Wang, H. Ye, C. Tian, S. Hao, Y. Yang, "Metal-organic framework-derived $\mathrm{N}$-rich porous carbon as an auxiliary additive of hole transport layers for highly efficient and long-term stable perovskite solar cells," Sol. RRL, 4, 1900380 (2019).

162. P. Schulz, D. Cahen, A. Kahn, "Halide perovskites: is it all about the interfaces?" Chem. Rev., 119, 3349-3417 (2019).

163. Q. Chen, H. Zhou, Z. Hong, S. Luo, H.-S. Duan, H.-H. Wang, Y. Liu, G. Li, Y. Yang, "Planar heterojunction perovskite solar cells via vaporassisted solution process," J. Am. Chem. Soc., 136, 622-625 (2014).

164. Y. Shi, X. Wang, H. Zhang, B. Li, H. Lu, T. Ma, C. Hao, "Effects of 4-tert-butylpyridine on perovskite formation and performance of solution-processed perovskite solar cells," J. Mater. Chem. A, 3, 22191-22198 (2015).

165. P.W. Liang, C.Y. Liao, C.C. Chueh, F. Zuo, S.T. Williams, X.K. Xin, J. Lin, A.K.Y. Jen, “Additive enhanced crystallization of solution-processed perovskite for highly efficient planar-heterojunction solar cells," Adv. Mater., 26, 3748-3754 (2014). 
166. M.-R. Ahmadian-Yazdi, and M. Eslamian, "Toward scale-up of perovskite solar cells: annealing-free perovskite layer by low-cost ultrasonic substrate vibration of wet films," Mater. Today Commun., 14, 151-159 (2018)

167. M.Y. Cha, P.M. Da, J. Wang, W.Y. Wang, Z.H. Chen, F.X. Xiu, G.F. Zheng, Z.S. Wang, "Enhancing perovskite solar cell performance by interface engineering using $\mathrm{CH}_{3} \mathrm{NH}_{3} \mathrm{PbBr}_{0.9} \mathrm{I}_{2.1}$ quantum dots," J. Am. Chem. Soc., 138, 8581 (2016).

168. M.M. Tavakoli, R. Tavakoli, S. Hasanzadeh, M.H. Mirfasih, "Interface engineering of perovskite solar cell using a reduced graphene scaffold," J. Phys. Chem. C, 120, 19531-19536 (2016).

169. S. Ito, S. Tanaka, K. Manabe, H. Nishino, "Effects of surface blocking layer of $\mathrm{Sb}_{2} \mathrm{~S}_{3}$ on nanocrystalline $\mathrm{TiO}_{2}$ for $\mathrm{CH}_{3} \mathrm{NH}_{3} \mathrm{PbI}_{3}$ perovskite solar cells," $J$. Phys. Chem. C, 118, 16995-17000 (2014).

170. S. Carretero-Palacios, M.E. Calvo, H. Míguez, "Absorption enhancement in organic-inorganic halide perovskite films with embedded plasmonic gold nanoparticles," J. Phys. Chem. C, 119, 18635-18640 (2015).

171. G.S. Han, H.S. Chung, B.J. Kim, D.H. Kim, J.W. Lee, B.S. Swain, K. Mahmood, J.S. Yoo, N.-G. Park, J.H. Lee, H.S. Jung, "Retarding charge recombination in perovskite solar cells using ultrathin $\mathrm{MgO}$-coated $\mathrm{TiO}_{2}$ nanoparticulate films," J. Mater. Chem. A, 3, 9160-9164 (2015).

172. N. Aeineh, E.M. Barea, A. Behjat, N. Sharifi, I. Mora-Sero, "Inorganic surface engineering to enhance perovskite solar cell efficiency," ACS Appl. Mater. Interfaces, 9, 13181-13187 (2017).

173. D. Shen, Pang, Y. Li, J. Dou, M. Wei, "Metal-organic frameworks at interfaces of hybrid perovskite solar cells for enhanced photovoltaic properties," Chem. Commun., 54, 1253 (2018).

174. T.H. Chang, C.W. Kung, H.W. Chen, T.Y. Huang, S.Y. Kao, H.C. Lu, M.H. Lee, K.M. Boopathi, C.W. Chu, K.C. Ho, "Planar heterojunction perovskite solar cells incorporating metal-organic framework nanocrystals," Adv. Mater., 27, 7229 (2015).

175. M.-R. Ahmadian-Yazdi, N. Gholampour, M. Eslamian, "Interface engineering by employing zeolitic imidazolate framework-8 (ZIF-8) as the only scaffold in the architecture of perovskite solar cells,"
ACS Appl. Energy Mater., 3, 3134-3143 (2020).

176. T.M.H. Nguyen, and C.W. Bark, "Highly porous nanostructured $\mathrm{NiO} @ \mathrm{C}$ as interface-effective layer in planar n-i-p perovskite solar cells," J. Alloys Compd., 841, 155711 (2020).

177. W. Zhang, J. Song, D. Wang, K. Deng, J. Wu, L. Zhang, "Dual interfacial modification engineering with p-type $\mathrm{NiO}$ nanocrystals for preparing efficient planar perovskite solar cells," J. Mater. Chem. C, 6, 13034-13042 (2018).

178. H. Taherianfard, G. Kim, F. Ebadi, T. Abzieher, K. Choi, U.W. Paetzold, B.S. Richards, A.A. Eliwi, F. Tajabadi, N. Taghavinia, M.M. Byranvand, "Perovskite/hole transport layer interface improvement by solvent engineering of spiroOMeTAD precursor solution," ACS Appl. Mater. Interfaces, 11, 44802-44810 (2019).

179. W. Zhang, X. Zhang, T. Wu, W. Sun, J. Wu, Z. Lan, "Interface engineering with $\mathrm{NiO}$ nanocrystals for highly efficient and stable planar perovskite solar cells," Electrochim. Acta, 293, 211-219 (2019).

180. T. Leijtens, G.E. Eperon, N.K. Noel, S.N. Habisreutinger, A. Petrozza, H.J. Snaith, "Stability of metal halide perovskite solar cells," Adv. Energy Mater, 5, 1500963 (2015).

181. Z. Wang, Z. Shi, T. Li, Y. Chen, W. Huang, "Conjugated polymers: catalysts for photocatalytic hydrogen evolution," Angew. Chem., Int. Ed., 55, 2 (2016).

182. G.D. Niu, X.D. Guo, L.D. Wang, "Review of recent progress in chemical stability of perovskite solar cells," J. Mater. Chem. A, 3, 8970 (2015).

183. C.-C. Lee, C.-I. Chen, Y.-T. Liao, K.C.-W. Wu, C.-C. Chueh, "Enhancing efficiency and stability of photovoltaic cells by using perovskite/Zr-MOF heterojunction including bilayer and hybrid structures," Adv. Sci., 6, 1801715 (2019).

184. Z. Xiao, Q. Dong, C. Bi, Y. Shao, Y. Yuan, J. Huang, "Solvent annealing of perovskite-induced crystal growth for photovoltaic-device efficiency enhancement," Adv. Mater, 26, 6503 (2014).

185. O.M. Bakr, and O.F. Mohammed, "Shedding light on film crystallization," Nat. Mater., 16, 601 (2017).

186. D.P. McMeekin, Z. Wang, W. Rehman, F. Pulvirenti, J.B. Patel, N.K. Noel, M.B. Johnston, S.R. Marder, 
L.M. Herz, H.J. Snaith, "Crystallization kinetics and morphology control of formamidinium-cesium mixed-cation lead mixed-halide perovskite via tunability of the colloidal precursor solution," $A d v$. Mater., 29, 1607039 (2017).

187. C. Chiang, M.K. Nazeeruddin, M. Gratzel, C. Wu, "The synergistic effect of $\mathrm{H}_{2} \mathrm{O}$ and DMF towards stable and 20\% efficiency inverted perovskite solar cells," Energy Environ. Sci., 10, 808 (2017).

188. T. Singh, and T. Miyasaka, "Stabilizing the Efficiency beyond $20 \%$ with a mixed cation perovskite solar cell fabricated in ambient air under controlled humidity," Adv. Energy Mater., 8, 1700677 (2017).

189. M. Li, D. Xia, A. Jiang, X. Du, X. Fan, L. Qiu, P. Wang, R. Fan, Y. Yang, "Enhanced crystallization and optimized morphology of perovskites through doping an indium-based metal-organic assembly: achieving significant solar cell efficiency enhancements," Energy Technol., 7, 1900027 (2019).
190. E.J. Juarez-Perez, Z. Hawash, S.R. Raga, L.K. Ono, Y. Qi, "Thermal degradation of $\mathrm{CH}_{3} \mathrm{NH}_{3} \mathrm{PbI}_{3}$ perovskite into $\mathrm{NH}_{3}$ and $\mathrm{CH}_{3} \mathrm{I}$ gases observed by coupled thermogravimetry-mass spectrometry analysis," Energy Environ. Sci., 9, 3406 (2016).

191. X. Zhou, L. Qiu, R. Fan, J. Zhang, S. Hao, Y. Yang, "Heterojunction incorporating perovskite and microporous metal-organic framework nanocrystals for efficient and stable solar cells," Nano-Micro Lett., 12, 80 (2020).

192. C.-C. Chueh, C.-I. Chen, Y.-A. Su, H. Konnerth, Y.J. Gu, C.-W. Kung, K.C.-W. Wu, "Harnessing MOF materials in photovoltaic devices: recent advances, challenges, and perspectives," J. Mater. Chem. A, 7, 17079-17095 (2019).

193. D.Y. Heo, H.H. Do, S.H. Ahn, S.Y. Kim, "Metalorganic framework materials for perovskite solar cells," Polymers, 12, 2061 (2020).
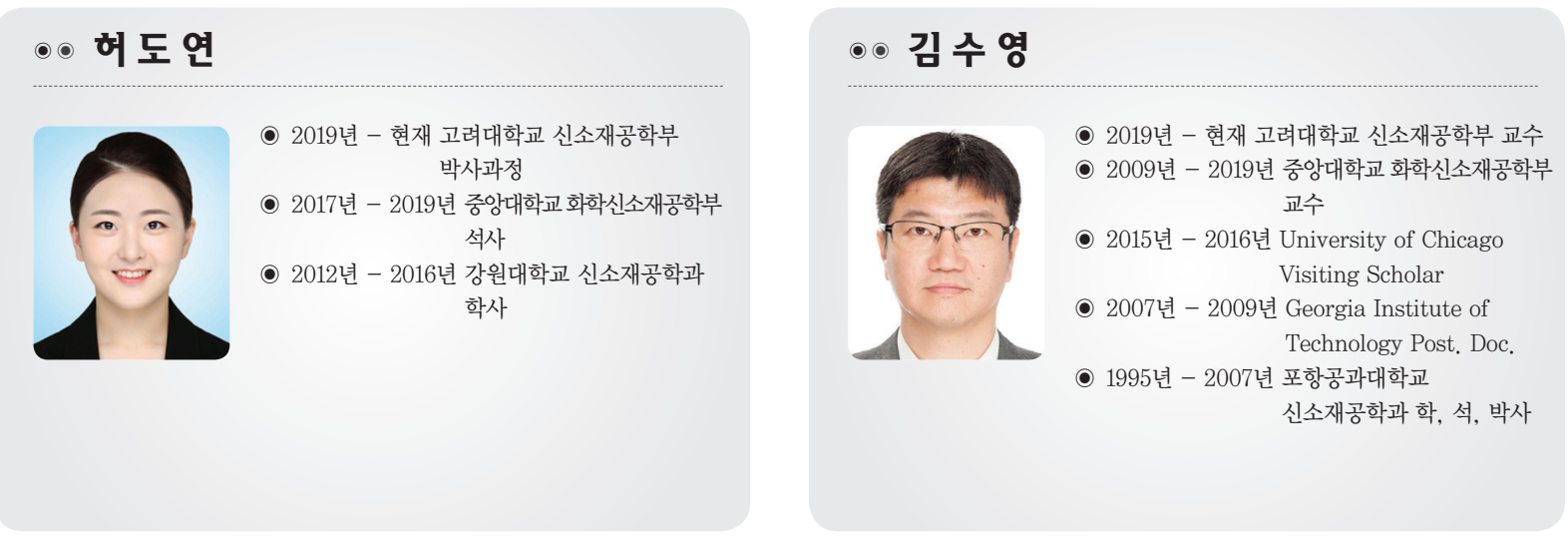